\title{
Women and Science in the Netherlands: A Dutch Case?
}

\section{Mineke Bosch}

Center for Gender and Diversity, University Maastricht

\section{Argument}

A recent comparative study of women in science has revealed that the situation in the Netherlands is worse than in other European countries. This raises the question whether there is a "Dutch case" concerning women's standing in science. We argue that the cause is not to be found in a special brand of Dutch Protestantism, with its strong emphasis on motherhood and the family, and impact on labor patterns and social organization. Rather, we should take another look at religion, and especially at the specific Dutch segmentation of society along religious and political lines, called verzuiling, literally "pillarization." From about 1880 until far into the 1950s the personal and social life of the Dutch (from schools to sports and ladies' organizations) was organized into four recognized pillars (a Protestant, Catholic, socialist and a liberal pillar), which at the top were represented in political parties. This article brings to light the often overlooked fact that between 1880 and 1945 state institutions, such as universities, were thoroughly pillarized, which strongly influenced recruitment and selection for those institutions. That is to say, no woman was appointed to the rank of full professor at any state university until after 1945. The Dutch case might also be explained by the many reorganizations and down-sizings of universities of more recent years that occurred simultaneous with the expansion of academic feminism. In addition, a newly configured "pillarization" has driven deep divides between gender studies scholars, equal opportunities officers, and women scientists.

But even in the long-industrialized European countries, the story has not been one of automatic growth and progress. Thus ... in the Netherlands ... there too the situation for women academics has deteriorated over the past two decades. Where in 1970 there were 2.7 per cent women professors, by 1980 this was down to 2.2 per cent and by 1988 to 2.1 per cent. (Rose 1994)

\section{Introduction}

In April 2000, the European Commission (EC) organized a conference in Brussels, "Making Change Happen." The aim was to discuss the EC's report Science Policies in 
the European Union. Promoting Excellence through Mainstreaming Gender Equality (EC 2000; hereafter European Commission) and to determine follow-up strategies for the report's findings. With regard to the Netherlands, the report made clear that in terms of a European (and global) comparative perspective, Dutch women in the field of science were not faring well. Although the report presented some good news about practices in the Netherlands, this was overshadowed by statistical negatives: one table in the European Commission report showed that the Netherlands came in last out of 24 nations with the lowest percentages of women in the rank of professor. Another table confirmed that the Netherlands has "the leakiest pipeline" of all. (European Commission 2000, table 2.1, p. 10 and table 2.4 (the scissors diagram), p. 13; for the "leaky pipeline," see p. 12). ${ }^{1}$ While the Netherlands comes in last for full professors (1998 figures), it is tied with Austria and Belgium with 7 per cent associate professors, and higher than Austria, Belgium, and Ireland with 20 per cent assistant professors. $^{2}$

On the fringes of the EU conference, there was a screening of a Dutch documentary called "Waste of Talent" that focused on the under-representation of women in science and research in the Netherlands, starting from the famous Swedish case of gender bias in the selection process of the Swedish Medical Research Council. ${ }^{3}$ This gender bias had convincingly been documented by Christine Wennerås and Agnes Wold, who subsequently published their findings in the leading journal Nature (Wennerås and Wold 1997). Their article alerted leaders in academic and research institutions to problems women face in science. The film also caught some remarkable opinions of the Dutch research establishment: a representative of the Royal Dutch Academy of Sciences (KNAW), for example, stated that women had to make choices - that women who really wanted to be professors had to realize that they could no longer sew their own clothes.

At this conference in Brussels the idea of a "Dutch case" (as the worst case) was born. The dismal statistics as well as the opinions recorded in the documentary suggested that something odd was going on behind Dutch dikes. How could it be that a country known for its traditions of tolerance and liberty in matters of religion and sexuality - a country in which gay men and women can legally marry, in which a rational and non-moralistic policy on drugs is pursued, a country proud of its republican system which advocates nonhierarchical difference over sharp social

\footnotetext{
${ }^{1}$ The three highest ranks in Dutch universities - professor, universitair hoofdocent (UHD), and universitair docent (UD) - correspond to the American ranks of full, associate, and assistant professor. In the Netherlands, however, these ranks cannot be attained by good performance, they refer to fixed positions and not to a tenure track. Formerly they were called professor, lector, and universitair (hoofd) medewerker.

${ }^{2}$ The Netherlands is doing worse than Germany, a country which until far into the 1980 s could be compared with the Netherlands (see Hawkins and Schultz 1990).

${ }^{3}$ The documentary "Verlies van talent" (Waste of Talent) was made by Marjan Tjaden for the TV series Noorderlicht (Northern Light) of the Broadcasting Association VPRO. It was shown on 6 February 1998.
} 
inequalities - remain so backward when it comes to women and equal opportunities in science?

This article will explore the possibility of "a Dutch case" regarding the underrepresentation of women in science. Is Dutch science or are Dutch universities lagging behind other countries in respect to equal opportunities for women? A very first answer is both yes and no. On the one hand, there is no unique Dutch case. For example, the impression - based on comparative figures - that in Finland and Great Britain women fare better in science is misleading. Because of the restructured ranking systems in Finland and the fusion of polytechnics with universities in Great Britain, the reported figures for these countries appear better, but in reality they report different categories than in the Netherlands. On the other hand, there are factors at play within the Netherlands, as indeed there are in every country, which function to create a unique nation-specific scenario. What are these factors? And, can these factors be attributed to long-term historical factors, such as the influence of religion, or conceptions of labor or the family? Or is the current situation simply a product of more recent developments, such as university reform, or ineffective equal opportunities policies? To what degree is the situation part of a "general Dutch case" (reflecting Dutch women's comparatively unstable social-economic position) and to what degree is it a case born out of Dutch academic traditions or the organization of the sciences particular to this country? In this essay, "science" refers, in the continental sense, to science as the whole spectrum of sciences and the humanities (wetenschap, Wissenschaft), and women's participation in it primarily in the context of academia.

\section{Part I. Women in Science in the Netherlands: A Historical Perspective on "the Dutch case"}

\section{Getting in: female students in the Netherlands}

Aletta Jacobs (1854-1929): from first female academic to feminist politician

In the nineteenth century, when women everywhere in the western world were knocking on university doors, in the north of the Netherlands the Jewess Aletta Jacobs became the first woman to enroll as a medical student. On 20 April 1871, Jacob's name, in her own handwriting, appeared in the Album Studiosorum of the State University of Groningen (Jacobs [1924] 1996; see also Bosch 1990, De Wilde 1979, and De Wilde 1998). The story of her entrance is simple. While demonstrating to a family friend her proficiency in Latin, a skill she had learned from her father, Aletta revealed her unhappiness at the lack of educational opportunities available to girls in her small provincial town. The friend, L. Ali Cohen, was a medical inspector and leading figure in the profession, and he suggested she take the assistant apothecary's 
examination, an option that had just been opened to women the previous year. After she passed the exam one year later, another friend of her father, professor of medicine and Rector of the State University of Groningen, S. S. Rosenstein, pointed out that some students had received permission to enter the university on the basis of the assistant apothecary's exam. Aletta Jacobs wrote to the prime minister, J. R. Thorbecke (an important liberal reformer), requesting exemption from the university entrance requirement and permission to attend university classes. Thorbecke granted this permission in a letter to her father, stating that if Mr. Jacobs had no hesitations, Thorbecke would raise no objections either. However, Aletta would be required to renew her exemption request when she was ready to take her first official exam. A year later, when a rumor circulated that Thorbecke was seriously ill, Jacobs's father wrote to him, indicating the courses Aletta had already successfully completed and requested that she be granted the necessary dispensation to continue. A few days later, a black-edged letter containing the final dispensation arrived. It was one of Thorbecke's last official acts before he died. From then on, Aletta Jacobs studied in Groningen and Amsterdam and, after having defended her thesis "On the Localization of Physiological and Pathological Symptoms in the Cerebrum," she received her degree on 8 March 1879.

Aletta Jacobs did not intend to pursue a laboratory or scientific career. She wanted to make use of her education to improve the position of women in the Netherlands. After receiving her medical degree, she went to London, where she met Elizabeth Garrett Anderson, the second woman to be officially registered as a doctor in the UK, and her sister Millicent Garrett Fawcett, the long-time leader of the National Union of Women's Suffrage Societies. Through introductions by the radical liberal Carel Gerritsen, whom she later married, Jacobs also became acquainted with free-thought campaigners and Malthusians, such as Charles Bradlaugh, Charles and George Drysdale, and Annie Besant, who taught her various methods of birth control. In the 1880s she corresponded with a German doctor, Mensinga, about a pessary that she began to prescribe as a contraceptive. It was originally known as "Mensinga-pessary," but later became famous - especially in the United States - as the "Dutch pessary," substantially because of Jacobs's efforts. She also had an interest in women's political rights, which is evident in her attempt to register to vote in 1883 . Her request was turned down by the city council, a decision she fought, unsuccessfully, all the way to the High Court. In 1894, she helped found and direct the Dutch Woman Suffrage Association from 1903 until Dutch women received the vote in 1919.

Although Jacobs turned out to be more of a politician than a medical woman or feminist theoretician, her accomplishments served to secure her a prominent role in the Dutch women's suffrage movement. Certainly, her reputation as the first university-educated woman in the Netherlands was important. She also gave the movement in the Netherlands a broader philosophical base by translating into Dutch Charlotte Perkins Gilman's Women and Economics (in 1900) and Olive Schreiner's Woman and Labour (in 1910). 
Aletta Jacobs' admittance to university - certainly when compared to the experiences of German and British women - seems to show Dutch tolerance (Boehm 1958; Soden 1979; Brittain 1960; Burstyn 1980). However, although all Dutch universities (three at the time) were state institutions and subject to the same regulations, Jacobs' admission proved to be the exception rather than the rule (Baranelli 1990; Bertels 1986; Lucassen and Peeters 1988). One year after Jacobs was admitted, two Russian women, Olga von Stoff and Fanny Berlinerblau (later Fanny Berlin), were denied admission to the medical school in Leiden, despite the university's long tradition of admitting foreigners, particularly those facing discrimination elsewhere (Bosch 1994, 93-94). Both women had started their medical education three years earlier in Zürich, but had to leave because of the Russian ukase, which forbade female students from continuing their studies in that "revolutionary" city (Bonner 1992). Although Dutch universities did not explicitly refuse to admit women, it was a decade after Jacobs before another woman applied to a medical school. This was Catharine van Tussenbroek, 1852-1925 (Schoon 1989; Bosch 1994, ch. 4). Until 1898 only a handful of women became regular students (Jansing and Dasberg 1978; Jensma and De Vries 1997).

The year 1898 marked a turning point. In that year, Dutch women organized a large National Exhibition of Women's Labor, symbolically using the occasion of young Queen Wilhelmina's ascension to the throne to present their case (Grever and Waaldijk 1998; Posthumus-van der Goot and De Waal [1948] 1977). Although women's participation in science or academic education was not a central issue at the exhibition, it did spark a widely publicized debate concerning women's higher education. A young gynecologist and professor at Amsterdam University, Hector Treub, who was sympathetic toward the cause of education for women, responded to the question "Is woman fit for science, and science fit for woman?" with a resounding “yes" (Kloosterman 1992; Treub and Winkler 1898; Bosch 1994). His statement provoked several counter-attacks, reminiscent of earlier works by Harvard professor Edward Clarke and London University College professor Henry Maudsly (Clarke 1873; Maudsley 1874; Burstyn 1980). One Dutch psychiatrist reduced the question of sexual equality to a simple social- (or rather sexual-) Darwinist scheme, and declared that in his opinion female scientists were "monsters" (Cox 1898). One of Treub's colleagues at Amsterdam, Cornelis Winkler, argued more politely that female academics, by ignoring that "biology is destiny," threatened social fecundity through education-induced sterility (Treub and Winkler 1898). One of the few feminist voices in this debate was that of Catharine van Tussenbroek, who became a leading gynecologist, combining clinical practice with research. She electrified the National Exhibition of Women's Labor with her opening speech on the lack of vital energy in young women caused by society's expectations that girls should wait for a husband instead of prepare for meaningful work (Tussenbroek [1898] and Tussenbroek 1898; also Bosch 1994 and Grever and Waaldijk 1998). After 1898, the number of Dutch female university students rapidly increased (see Table 1). 
Table 1: Female Students Per Faculty Per Year (totals and percentages)

\begin{tabular}{|c|c|c|c|c|c|c|c|c|c|}
\hline & 1898 & & & 1928 & & & 1940 & & \\
\hline & Total & Female & $\%$ & Total & Female & $\%$ & Total & Female & $\%$ \\
\hline Theology & 393 & 1 & & 678 & 42 & 6,2 & 779 & 71 & 9.1 \\
\hline Law & 476 & 5 & & 1,590 & 262 & 16,5 & 1,610 & 430 & 26.7 \\
\hline $\begin{array}{l}\text { Law and } \\
\text { Arts }\end{array}$ & & & & 337 & 15 & 4,5 & 375 & 49 & 13.1 \\
\hline Medicine & 1,126 & 29 & 2.3 & 3,125 & 374 & 12 & 3,470 & 634 & 18.3 \\
\hline $\begin{array}{l}\text { Math and } \\
\text { Natural } \\
\text { Science }\end{array}$ & 402 & 48 & 11.9 & 1,862 & 508 & 27,3 & 1,437 & 418 & 29.1 \\
\hline $\begin{array}{l}\text { Geography } \\
\text { and } \\
\text { Psychology }\end{array}$ & & & & 57 & 15 & 26,3 & 112 & 52 & 46.4 \\
\hline $\begin{array}{l}\text { Philosophy } \\
\text { and } \\
\text { Literature }\end{array}$ & 178 & 18 & 10.8 & 1,224 & 561 & 45,8 & 865 & 380 & 43.9 \\
\hline Economics & & & & 159 & 22 & 13,8 & 190 & 18 & 9.5 \\
\hline $\begin{array}{l}\text { Veterinary } \\
\text { Science }\end{array}$ & & & & 158 & 1 & 0,5 & 135 & 7 & 5.2 \\
\hline $\begin{array}{l}\text { Technology } \\
\text { and } \\
\text { Agriculture }\end{array}$ & & & & & $\begin{array}{l}113 \\
(\star)\end{array}$ & & 2,778 & 119 & 4.3 \\
\hline Total & 2,716 & 101 & 3.7 & 9,561 & 1,810 & 18.9 & 11,251 & 2,044 & 18.2 \\
\hline
\end{tabular}

Source: Jensma and De Vries 1997, 193, 204, 210.

Source ( $\left.{ }^{\star}\right)$ : Freie 1948.

\section{Never just about women: discourses of gender and science, 1898-1948}

The 1898 debate concerning women's abilities in the field of science has often been interpreted as the last serious effort to bar women from higher education. However, women were in academic institutions to stay, and 1898 marked the beginning of a new discourse about "women's particular place" in science. It took place almost daily 
in diverse venues: speeches opening the academic year, addresses opening conferences, necrologies, vocational guidebooks, government documents setting policy for higher education, and in histories of disciplines and laboratories. Although the specific arguments changed over time and shifted according to specific contexts, the function of the debate remained the same, namely to define the place of women in science. ${ }^{4}$ The result of this "restrictive logic," to use Margaret Rossiter's term, has been women's limited access to science (Rossiter 1984, xvii).

What complicates the picture in these debates is that they are never just about "women" or, explicitly about the social relations between the sexes in science. Ideas about women and science (and implicitly about men and science) can also contribute to creating hierarchies between sciences and within disciplines, tasks, and functions in terms of gender. ${ }^{5}$ Directly or indirectly such discourses produce and reinforce horizontal and vertical segregation, which is often explained only in terms of "women's preference." 6

Thus, in 1898, at the same time that women's access to higher education was at stake, the concepts of higher education, science, and what it meant to be a scientist were being redefined. The nineteenth-century "man in the lab," as Londa Schiebinger aptly labeled the heroic figure of the scientist who pursues his goal day and night, undistracted by private or bodily cares, was not as yet well established (Schiebinger 1989)..$^{7}$ At this time this image was still overshadowed by the older image of the learned man whose training departed from the classics and whose authority depended on elite status rather than scientific merit. Eventually the newer image would triumph and signify an ideal that few women could achieve. The image of the scientist as a heroic "man in the lab" which was upheld in the debates on "women and science" therefore had the double effect of redefining the meaning of "science" to the narrower domain of "natural science" and of defining "natural science" as a "manly profession." After 1898, women were never again completely excluded from the broader realm of science. However, by reserving some disciplines (the humanities, languages, and pharmacy $^{8}$ ) for women and in the process feminizing these fields, the "real" natural sciences became masculinized.

\footnotetext{
${ }^{4}$ In the introduction to her work on women scientists in America, Rossiter uses the phrase "women's historically subordinated 'place' in science" (Rossiter 1984, xv).

${ }^{5}$ A widely accepted definition of gender - going back to Joan Scott - is that languages of gender not only serve to give meaning to the relations between the sexes, but also serve to give meaning to power and construct power and power differences (Scott 1988).

${ }^{6}$ The unequal distribution of women over the disciplines (or the question of how disciplines produce gender and vice versa) has until now hardly received any systematic attention. There is sensitivity to the differences between disciplines regarding gender, but not to how these differences come about, or what explains them. Exceptions are Honegger's study of the origin of the social sciences (Honegger 1992) and Rossiter's study of the many differences within the natural sciences (Rossiter 1997).

${ }^{7}$ How influential this figure still is, was more recently pointed out by Naomi Oreskes (Oreskes 1996).

${ }^{8}$ Martha Kirejzyk has rightly pointed out that at the turn of the century the faculty of natural science attracted the largest number of women, due to the study of pharmacy. Pharmacy, however had a much lower status than physics or mathematics, and led to an already well-known women's career outside the university, almost never to a career in science. Only 22 out of 596 women doctors earned a Ph.D. (Kirejzyk 1993).
} 
The reason Winkler intervened in the debate about women and science is only clear when seen in the context of his efforts to create a new division within the medical profession between general practitioner and scientific specialist. In the debate about women and science, he aptly used the gendered associations of theory (masculine) and practice (feminine), thereby excluding women from scientific careers, but including them in nursing or general practice. This not only limited women's access to the medical profession, but also strengthened his case for these basic divisions within the profession (Winkler [1901] 1918; Bosch 1994). Similarly, the harsh criticism directed at "girl-students" by the history professor at Leiden, P. J. Blok in 1907 can be explained in the context of his efforts to professionalize historical science (Blok 1907). In his opinion only men were capable of pursuing "the heroic and solitary quest for truth," because "the female brain lacks impartiality. By nature it is superficial and becomes focused unnecessarily upon one single fact instead of the cohesion of facts" (cited in Grever 1997; see also Bosch 1994; for an elaborate study of gender and the historical profession, see Grever 1994). Like Winkler, Blok advocated that women be included in the infrastructure of the historical profession as "assistant archivist" or "assistant librarian," fields that were already feminized. That again had the effect of making the core business of historical research a decidedly male pursuit.

In the 1920s and 1930s, women's place in higher education was contested not so much in terms of women's capacities or brains, or specific fields and functions, but in terms of the general social and economic value of higher education. In a lecture on the relation between university and society, the chemist H. R. Kruyt argued that Dutch universities produced "learned men" while Dutch polytechnics had been downgraded to simple professional schools (Kruyt 1930; Bosch 1994). The Dutch, he recommended, should look to the United States, where universities contributed directly to society. ${ }^{9}$ He recommended further that natural scientists, industrialists, and other professionals be appointed to university boards with the aim of demoting the old elite with their heavy commitment to the humanities and law, and promoting instead the new elite of natural scientists.

This plea for a university system that stressed the social value of the natural sciences over the humanities (a plea later repeated in C. P. Snow's Two Cultures) did not bode well for women. Not only were women drastically under-represented in the natural and technical sciences in this period, they were under-represented precisely because of the widespread notion that a woman's education should be directed toward general knowledge to make her a better wife and mother, and not toward a profession or a scientific career. Although the Dutch never implemented explicit quotas for women, as was done in Oxford in 1927 and in Nazi Germany in 1933, the constant worry

\footnotetext{
${ }^{9}$ Other academic leaders at that time (among them the historian Huizinga) noted that there was not a marked division between general education, professional education, and graduate education in the American college and university system and the choice was less determined by social class. The mutual influence of science and society was always seen in the connection between alumnae and university (Berkel 1990).
} 
Table 2: University Students in the Netherlands, 1898-1970

\begin{tabular}{lccc}
\hline & Total & Female & \% Female \\
\hline $\mathbf{1 8 9 8}$ & 2,716 & 101 & 3.7 \\
\hline $\mathbf{1 9 2 8}$ & 9,561 & 1,810 & 18.9 \\
\hline $\mathbf{1 9 4 0}$ & 11,251 & 2,044 & 18.2 \\
\hline $\mathbf{1 9 6 0}$ & 40,727 & 7,305 & 17.9 \\
\hline $\mathbf{1 9 7 0}$ & 102,219 & 29,995 & 19.8 \\
\hline
\end{tabular}

Source: Freie 1948; Bosch 1999.

about over-crowded laboratories or female's failure to contribute to the labor market had the effect of limiting females to 20 per cent of the student body well into the 1960s (Brittain 1960; Weyrather 1981; for Dutch discourses on overcrowding, see Idenburg, 1934; De toekomst 1936; and Bosch 1994, ch. 9) (see Table 2).

The debate over women's place in science took another turn immediately after World War II, when a commission was set up in 1947 to reorganize Dutch higher education (Rapport van de staatscommissie 1949; Bosch 1994, ch. 10; Rupp 1997). In response to the war, debates about the purposes of university education changed yet again. Instead of preparing students for a professional career, the university was now to be organized to provide a general humanist education, focusing on moral and ethical responsibility of autonomous persons in times of war. Theoretically, such an approach should have provided women with more opportunities. The few women invited to participate in this state commission, however, were placed on one subcommittee whose task it was to consider "women and higher education." They were pressured to develop a special "women's curriculum" focusing on psychology and pedagogy. Despite the popular arguments that women had a special contribution to make through their feminine difference, the women's committee of 1947 was able to prevent the formalization of a special women's curriculum that would have marginalized academic women.

\section{Dutch Women and the "Second Golden Age": Horizontal Segregation}

The gendered division between science and the humanities occurred in the Netherlands in the second half of the nineteenth century. Although many late twentieth-century authors suggest that the relationship between women and the natural sciences had been adversarial from their beginnings in the scientific revolution, one may wonder why it seemed so necessary in the nineteenth-century 
debate about women and science to stress the masculinity of the natural scientific enterprise. Could it be that doubts existed regarding the "manliness" of the scientific profession, and that this uncertainty spilled into the debates?

In her book, The Scientific Lady, Patricia Phillips claims that the relationship between women and the sciences flourished in seventeenth- and eighteenth-century Great Britain, and did not become strained until in the second half of the nineteenth century when an important secondary school reform took place (Phillips 1990). The same is true for the Netherlands. ${ }^{10}$ Although the Netherlands did not produce bestselling female science writers, such as Priscilla Wakefield or Jane Marcet, or female scientists of the stature of Mary Sommerville, Dutch women did foster the "new experimental philosophy" as useful and claimed that it would lead to a knowledge of divine creation (Bosch 1998). The German-born Maria Sybilla Merian, renowned for mapping Surinam insects, remained exceptional (Schiebinger 1989). More commonly in eighteenth-century Holland, authors of popular science were men of God, as was the case of the vicar who penned the Catechismus der Natuur (Catechism of Nature) and taught his lessons to a ladies' group. At the end of the eighteenth century the only Ladies' Physical Society in the world was founded in Middelburg, which should be interpreted as an early expression of middle-class gender segregation, rather than as a sign of feminist activism (Sturkenboom 2001). As a matter of fact, girls' education in the nineteenth century commonly included science education, even though it was presented in a "domestic" format, such as a dialogue among friends or as a board game (Bosch 1998).

Any positive relationship between women and science cultivated in the Netherlands in an earlier age, however, had soured by the last quarter of the nineteenth century as a consequence of educational reform and the rapid expansion of Dutch science. The period after 1863 is known as the "Second Golden Age" not least because six Dutch scientists won Nobel Prizes by the first decade of the twentieth century (Willink 1980; Berkel 1985; Berkel 1998). The "Second Golden Age" dawned with the reform acts of 1863 and 1876 that created the modern twotiered educational system. The most important creation of the 1863 Secondary Education Act was the Higher Burgher School (HBS) and its goal to prepare middle-class boys for careers in business or the technical trades (Idenburg 1960). ${ }^{11}$ When it was first established, the HBS was not intended to lead to a university education, but, could lead to education at the Polytechnical School at Delft (today Technical University) where engineers were trained. The HBS curriculum was set up as an alternative to the gymnasium with its traditional classical education, and it emphasized the natural sciences, modern languages, and accounting. Many schools were equipped with excellent laboratories for physics and chemistry, good collections

\footnotetext{
${ }^{10}$ Phillips' and my own research throw into doubt presentist judgments that women's curricula in the beginning of the nineteenth century were exceptional or even "prefeminist."

${ }^{11}$ Recently the centrality of educational reforms in the historiography of the "Second Golden Age" has been criticized as being "too narrow and even erroneous" by Maas, who notes the importance of the parallel development of individual entrepreneurship and innovation in Dutch culture (Maas 2001).
} 
for geography and biology, and some even had experimental gardens. Teachers specialized in one or more fields and were paid well. However, eventually the HBS did begin to supply students to universities, especially in the fields of medicine and the natural sciences, granting them special privileges to gain entrance and promotion. In 1917 a special act formally granted HBS-educated students admission to a Ph.D. program, though only in the faculties of medicine and natural sciences (Groen 1987)..$^{12}$

Social class and for that matter, gender difference - not individual merit or learning - still lay at the heart of the Dutch educational system. The HBS schools were for boys of the middle classes while boys from academic and upper classes went to a gymnasium and subsequently to university. Nonetheless the university system underwent its own "scientific revolution" in step with the HBS system. The Higher Education Act of 1876 changed the university's goal. Instead of providing classical training as an introduction in the "learned classes," the university's goal was to teach young men to become independent researchers and prepare them for careers in science and society. Even though the gymnasium, with its classical curriculum, remained the formal path to university admission, Latin was abolished as the language of scholarly communication. The 1876 Act encouraged specialization and new disciplines in the faculties and sub-faculties and created new professorships in those disciplines. In addition, a considerable sum of money was invested in institutional infrastructure to build labs and purchase specialized equipment. These reforms, combined with the opportunities offered by the Netherlands' far-flung empire, led to a real boom in the natural sciences (Bossenbroek 1996; Bosch 2000).

Just as the late historian Joan Kelley asked, "Did women have a Renaissance?" we can pose the question, "Did Dutch women have a 'Second Golden Age'?" (Kelly 1984). Did they partake in the triumphs and the rewards? The answer is no. The 1863 law reforming secondary education did not explicitly exclude girls from the HBS, yet it implicitly did so by stating in one bylaw that the education of girls was the responsibility of the citizens themselves. This stimulated a lively debate about secondary education for girls (Essen 1990; Pouwelse 1993). What would be its purpose? Should it prepare women for marriage or work, and if for work, what kind of work? How should it be done, in co-educational or separate schools? And what should be on the program? In the course of these debates, the HBS curriculum became the point of comparison with the ideal curriculum for girls, and as a result, came to be seen as the ideal masculine education. In the $1860 \mathrm{~s}$, the first secondary schools for girls that strongly emphasized the humanities were founded. Unlike the (male) HBS, these schools would not lead to university. Despite these gender inequalities in the newly developed realm of secondary education, a few girls did

\footnotetext{
${ }^{12}$ In the nineteenth century, degrees were not considered so important, but the Ph.D. or doctorate degree, which a doctorandus could earn by writing a doctoral thesis or dissertation was the final degree. In 1921 the candidate's degree, as well as the doctoral (not doctorate) degree got effectus civilus, and from that moment the doctoral degree (Drs.), especially, can be seen as a final degree. The doctorate by then became a way to qualify for professional science.
} 
manage to enroll in the HBS as early as 1872 (among them one of Aletta Jacobs's sisters). Until 1906, however, women had to obtain permission from the central government to enroll as HBS-students.

What emerged in secondary and higher education, then, were two gendered tracks within a system of co-education. At the secondary school level privately funded girls schools did not prepare them for higher education. The natural sciences, due in large part to their connection to the HBS-curriculum's focus on practical issues and careers in industry or economics, became masculinized, while the humanities and a general education (and even the formerly male-identified classical education) became feminized. ${ }^{13}$ This can be seen in the increasing enrollment of women in the gymnasium (Table 3). It also explains why the social reformer, Helene Mercier, in her plea of 1876 for more women to enroll in the university, argued specifically for women's active participation in the moral teachings of "the Old" (Socrates, Plato, and Aspasia); her message emphasized that as keepers of classical learning, women could serve as a counterbalance to the growing dominance of "materialistic sciences." Mercier spoke for women and also against the growing prestige of the natural sciences

Table 3: Students M/F of Several Types of Secondary Education, 1898-1947

\begin{tabular}{|c|c|c|c|c|c|c|c|c|c|c|c|c|}
\hline & 1898 & & & 1911 & & & 1930 & & & 1947 & & \\
\hline & M & F & $\%$ & M & $\mathrm{F}$ & $\%$ & M & $\mathrm{F}$ & $\%$ & M & $\mathrm{F}$ & $\%$ \\
\hline Gymnasium & 2,265 & 155 & 7 & & & & 7,833 & 2,407 & 24 & 11,533 & 3,557 & 24 \\
\hline$\star 1900$ & & 230 & & & & & & & & & & \\
\hline HBS & 7,612 & 534 & 7 & 10,860 & 2,451 & 18.4 & 23,605 & 5,510 & 20 & 36,888 & 8,377 & 19 \\
\hline$\star 1900$ & & 855 & & & & & & & & & & \\
\hline $\begin{array}{l}\text { Lyceum } \\
\text { Secondary } \\
\text { School } \\
\text { Girls }\end{array}$ & & 1,706 & & & & & 8,487 & $\begin{array}{l}3,525 \\
1,924\end{array}$ & 29 & 31,683 & $\begin{array}{c}13,348 \\
4,617\end{array}$ & 30 \\
\hline
\end{tabular}

Source: Freie 1948.

Source (^1900): “De vrouw 1813-1913," Afdeeling Onderwijs. Statistische en andere mededelingen.

\footnotetext{
${ }^{13}$ The growing attractiveness of Latin and Greek for women is not specifically Dutch. Solomon has pointed out the increasing importance of the liberal arts curriculum at women's colleges: "In 1910 no one remembered that educators in the previous century thought women were incapable of learning Greek and Latin" (Solomon 1985, 81).
} 
and against attempts to remake medicine from an art into a science (Bosch 1994 and 1997; Wilde 1985). Mercier was convinced that women should be able to make important contributions to "science," but her definition of learning was based on the classics, which was fast becoming outmoded. The new masculinized "science" was natural science, and women were not to share in it and the "Second Golden Age" of Dutch culture that it came to represent.

Remaking and redefining science in the Netherlands in the last decades of the nineteenth century was supported by emerging notions of gender and questions about what type of learning was appropriate for each sex. Here the basis was laid for the horizontal gender segregation between the sciences and the humanities that still remains a major characteristic of academic life today.

\section{The exception that proves the rule: the relative success of Dutch female biologists in Dutch colonial perspective}

One exception to the strong masculinization of the natural sciences in late nineteenth-century Holland was the field of biology. Like today, this was a field where women were successful and visible. Johanna Westerdijk, who became the first woman professor in the Netherlands in 1917, was a biologist. Likewise, the second female professor appointed two years later, Tine Tammes (Wilde 1989; Stamhuis 1995). Because of institutional restrictions, both women earned their doctorates by circuitous routes. Westerdijk, after completing her exams to become a biology teacher in Holland, went to Zurich to take a doctorate in 1905. Tammes received an honorary Ph.D. from the University of Groningen in 1910. Two other female biologists also received honorary doctorates: Anna Weber-van Bosse from the University of Amsterdam in 1910 and Gerda Wilbrink from the University of Utrecht in 1922. Nearly half of all women who completed a university education in biology in this period earned a doctorate. The representation of women in the field is even higher when we take into account all the female biologists who trained for a teacher's exam and could not get an academic degree.

\section{Johanna Westerdijk (1882-1963): challenges and opportunities in colonial botany for Dutch women}

One explanation for the success of female biologists can be found in the formidable person of Johanna Westerdijk, who mocked the codes of high masculinity and femininity. Cigar smoking and (occasionally) trouser clad, she attracted considerable attention during a professional tour of agricultural research stations in the United States. Newspaper headlines read: "Dutch Woman Scientist Pities American Sisters"; "Westerdijk Says 'They Are Bound by Chains of Puritanism - They Lack Freedom Europeans Possess"”; "Botanist Objects to Ban on Fair Sex Smoking." Westerdijk 
criticized "smokers" that excluded women, as "ridiculous"; she was also critical of her male colleagues at a formal dinner who invited one "white-haired" female botanist so that (according to Westerdijk) their reputations were saved and the other female biologists in town had not to be invited. ${ }^{14}$

Westerdijk grew up in a culturally privileged Amsterdam family. Her father was a doctor; her French mother a gifted (amateur) musician. Johanna turned to botany, inspired by the "biological revival" that sent Dutch people from all walks of life on botanical excursions throughout all parts of the Netherlands. She enrolled at the University of Amsterdam, where the famous Hugo deVries reigned, even though she could prepare only for a teacher's exam. In pursuing her Ph.D. in Zürich, she was following in the footsteps of another Amsterdam woman, Mia Boissevain, the first Dutch woman to earn a doctorate in biology.

While still in Zurich, Westerdijk was invited to direct a small private Dutch laboratory for the study of plant diseases, the Willie Commelin Scholten Laboratory of Phytopathology (WCS-laboratory), founded in $1895 .{ }^{15}$ The laboratory had been left financially devastated by the former director who took the lab's resources (a statesubsidized contract for crop protection and the journal for phytopathology) with him to a newly founded institute at the School of Agriculture at Wageningen (Kerling et al. 1986; Löhnis 1963; Kerling 1969). Luckily for the WCS-laboratory, the influential professor of botany at Utrecht University, F. A. F. C. Went, still believed there was room for additional scientific research in this field, especially dealing with colonial agriculture (Schoor 1994). His staunch support for Westerdijk included asking her to curate the fungi collection of the Association Internationale des Botanistes. This collection grew to form the foundation for a new institute, the Centraal Bureau voor Schimmelcultures (Central Bureau for Fungi-cultures), which attracted much interest from scientists and industrial researchers. The institute was privately supported for many years by a former tea planter.

The WCS-laboratory also developed into an internationally recognized research institution. Between 1913 and 1915, Westerdijk visited the Dutch East Indies to study colonial phytopathology at various research stations. In 1919, she published a phytopathological system of classification in cooperation with the German biologist Otto Appel. This classification system paved the way for studying the anatomy of

\footnotetext{
${ }^{14}$ Westerdijk's criticism reinforces Margaret Rossiter's analysis of the function of "smokers" to exclude women from the networks of scientists: "Smoking and organized 'smokers', apparently an important and often deliberately intimidating part of the male professional culture at the turn of the century, greatly complicated the women's comprehension of whether or not they were actually welcome. Properly bred women apparently did not smoke or enter rooms where men were smoking before the 1920s.. . . Thus to include smoking on the program or to allow men to smoke after dinner was, whether men realized it or not, long an overt social message to the women not to attend" (Rossiter 1984, 92).

${ }^{15}$ The laboratory was founded by Mr. and Mrs. Scholten-Commelin in 1895 (the founding contract was signed in December 1894), in memory of their son, a biology student Willie Scholten. To his and his fathers last name the last name of his mother, Commelin, was added to the name of the laboratory. Several members of the famous Amsterdam Commelin family played major roles in the field of (colonial) botany. One of them was founder of the Amsterdam Botanical Garden.
} 
diseased plants, as well as the process of infection of healthy plants. It also focused on crop plants and ornamentals often neglected in pure botanical studies. In 1920, the laboratory moved from a small house in Amsterdam to a large and spacious mansion called Java in the "green village" of Baarn, formerly owned by Dutch plantation owners. The gardens bordered the beautiful "Cantonspark," which was part of the University of Utrecht's botanical gardens. In 1930, the coach house "Madura" was converted into a laboratory annex and party hall using private funds donated by one of the lab's first Ph.D. students and assistants, Marie Löhnis. Above the entrance was inscribed: Werken en feesten vormt schone geesten (Work and celebration make for creative spirits). Over the years, Westerdijk's lab hosted several international conferences and received visits from many foreign scientists.

In the meantime, on the initiative of Went, Westerdijk had been appointed buitengewoon professor (extraordinary professor) at the University of Utrecht in 1917 and at the University of Amsterdam in $1930 .{ }^{16}$ In this capacity, she attracted a large number (56) of Ph.D. students, almost half (23) of whom were women. Westerdijk was a strong supporter of female students and, through her hiring practices, turned her lab into one where women's representation was exceptionally high. She also used her influence as a professor to influence academic hiring: two of her South African female students became professors in their own country. Westerdijk was also active in the Dutch Association and International Federation of University Women, which she chaired from 1931 to 1938. In 1951, she was the second woman in the Netherlands to become a member of the Royal Dutch Academy of Sciences (Noordenbos 2000). ${ }^{17}$

Although she would have denied being a feminist, Westerdijk left her mark on the biology profession. She often ridiculed women's marriage expectations and made no secret of her preference for the unmarried state. Relying on her irresistible sense of humor, she established many rituals and traditions, and staged puppet shows or theater plays that poked fun at what Westerdijk saw as the pompous behavior of many academics. Cross-dressing was often part of these productions, with men acting as women and vice versa. She mocked the invasive way scientists investigate nature by personifying cabbages and potatoes, fungi and trees staging them in roles which turned upside down the usual division between subjects and objects of scientific research. ${ }^{18}$

The relative success of Dutch female biologists cannot, of course, be fully explained by Westerdijk's biography. Other factors were the traditional involvement

\footnotetext{
${ }^{16}$ The vital distinction between full or regular professor (ordinarius) and extraordinary professor (extraordinarius) is explained further on.

${ }^{17}$ The first member of the Royal Dutch Academy of Sciences was Christine MacGillavry, a crystallographer. Crystallography seems to have been a relatively feminized field in the 1950s and 60s.

${ }^{18}$ Several historians of science have analyzed the scientific image of nature as female, the passive gender to be dominated, explored, ravished, unveiled, searched, etc. Westerdijk in her fantasies gave an active role to "nature" vis-à-vis the exploring biologists.
} 
of women in botany and biology, the scientia amabilis, which Ann Shteir has discussed (Shteir 1996), and, more important, the competition which raged between academic biologists and vocational biologists for the colonial research market at the turn of the century (Bosch 2000). In this competition Went made use of old traditions and associations with learning to advance a scientific ideal of "pure science" and "fundamental research" done at universities as opposed to "applied science" done at the vocational School of Agriculture at Wageningen (Schoor 1994). In the process Went also mobilized the women botanists in upper-class family networks who felt encouraged to enter a career in biology.

\section{Women Scientists and the Pillarization of Academia: Vertical Segregation}

In 1948, on the occasion of Queen Wilhelmina's fiftieth Jubilee, Dutch women organized a large exhibition to display women's accomplishments. In conjunction with the exhibition, the Dutch Association of University Women prepared a quantitative study of women's representation in all scientific disciplines and in the labor market (Kolf 1950). Marie van der Kolf's statistical analysis focused on women who had completed an academic education. By consequently dividing the women into categories of "married," "unmarried," and "having been married," she could show that women were "as good as men," and that it was only due to marriage that women did not work outside the home as much as men. The majority of unmarried women certainly did have a career. One chapter summarized women's scientific rewards in terms of academic positions and honorary doctorates, showing that there were 11 female professors in the Netherlands (plus 2 who had taken their degrees in Holland but now taught at foreign universities), 14 lecturers (plus 6 teaching at foreign universities) and 84 other academic personnel (private lecturers, assistants, laboratory assistants, etc.). Overall, the tone of the book was optimistic. Even though barriers remained (especially outside academia in the realm of marriage and marriage law), unmarried women had proven their worth. ${ }^{19}$ This was all certainly meant to be good news; she could not avoid the implicit assessment, however, that, for women, science and marriage (and motherhood) were incompatible.

The central metaphor in the book invoked "frontier" language. Van der Kolf fancied women scientists "pioneers" who had entered "virgin" territory, and had "ploughed," "sowed," and "harvested" in the fields of science. Van der Kolf believed that women must be judged on their own merits, which explains why academic men were absent from the book (and the metaphors). Had she considered men, perhaps academic women would more properly have been figured "immigrants" rather than "pioneers" in science (see Table 4). Van der Kolf's optimism was based on a definition of science as an autonomous process separate from society. This definition became

\footnotetext{
${ }^{19}$ Marriage laws in the Netherlands until 1956 did not grant married women legal status as persons in their own right.
} 
Table 4: Female Academic Scientists in the Netherlands 1948

(Universities and higher vocational-economical, technical, agricultural-education)

\begin{tabular}{|c|c|c|c|c|c|c|c|}
\hline & Professor & $\begin{array}{l}\text { Lector } \\
\text { (Associate } \\
\text { Professor) }\end{array}$ & Other & $\begin{array}{c}\text { Total } \\
\text { university }\end{array}$ & Drs. & Ph.D. & Dr. $\%$ \\
\hline Theology & & & & & 98 & 7 & 7.1 \\
\hline Law & 1 & & 2 & 3 & 1,381 & 160 & 11.5 \\
\hline Medicine & 1 & 3 & 12 & 16 & 1,354 & 108 & 7.9 \\
\hline $\begin{array}{l}\text { Mathematics } \\
\text { and } \\
\text { Natural } \\
\text { Science }\end{array}$ & 3 & $5\left(+1^{\star}\right)$ & 41 & 49 & 1,106 & 204 & 18.4 \\
\hline 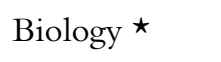 & 1 & 2 & 22 & 25 & 239 & 100 & 41 \\
\hline Pharmacy * & 1 & 2 & 4 & 7 & 596 & 22 & 3.6 \\
\hline $\begin{array}{l}\text { UF2: Arts } \\
\text { and } \\
\text { Natural } \\
\text { Science }\end{array}$ & 2 & 1 & 3 & 6 & 134 & 22 & 16.4 \\
\hline $\begin{array}{l}\text { Literature and } \\
\text { Philosophy }\end{array}$ & 4 & $4\left(+5^{\star}\right)$ & 24 & 32 & 1,117 & 243 & 21,8 \\
\hline Economics & & & & & 45 & 1 & 2 \\
\hline $\begin{array}{l}\text { Veterinary } \\
\text { Science }\end{array}$ & & & & & 8 & 1 & 12.5 \\
\hline $\begin{array}{l}\text { Technology } \\
\text { and } \\
\text { Agriculture }\end{array}$ & & 1 & 2 & & 247 & 12 & 4.8 \\
\hline Total & $11\left(+2^{\star \star}\right)$ & $14\left(+6^{\star \star}\right)$ & 84 & 109 & 4,109 & 598 & 14.5 \\
\hline
\end{tabular}

Source: Kolf 1950.

* Only biology and pharmacy in this table are shown specifically; they are included in the overall figures for mathematical and natural science.

$\star \star$ Graduated in the Netherlands, appointed at foreign universities. 
widely contested in later decades by historians and philosophers of science as well as by scientists themselves. The church historian, and sometime Rector of Utrecht University, Otto J. de Jong contributed to this debate by pointing out that between 1876 and 1931 the Ministers of Education, Culture and Science fundamentally "pillarized" the four state universities, by appointing Board members as well as professors according to a system of "equal representation" (Jong 1982). ${ }^{20}$

"Pillarization," or as it is also called, the "politics of accommodation" or "consociational democracy," is a central concept in Dutch history, referring to a specific Dutch variant of social segmentation in the age of state formation and the creation of a unified nation. The four (recognized) pillars (the orthodox protestants, Catholics, socialists, and a "neutral" liberal group) represented important segments of the Dutch population, which at the top were organized as a political party. State subsidies were divided according to pillars, and pillars completely dominated social and private life until far into the 1950 s (Blom en Talsma 2000; Rooy 2001). ${ }^{21}$ At the heart of the pillarization process was the political struggle about free (special or religious) - and state-subsidized - education; at the periphery were all social and cultural activities organized along these divided interests. The famous example mentioned here is always the art of goat breeding which had its several organizations: protestant, catholic, and socialist. Later the division of the broadcasting system became symbolic for twentieth-century segmentation (recently also called "ethnicitization") of Dutch society. "Mixed marriages" were a concept quite different from today, until far into the sixties.

Though pillarization has been studied often locally and in relation to social class and nation formation, the above mentioned study by De Jong has looked at a special case of pillarization, by asking the question: How did pillarization affect the organization of higher education and research in the Netherlands? In a way this is a revolutionary question, for it is a generally accepted opinion that although the nation was segmented the state kept its liberal (neutral) signature, and with the state also the state run institutions such as the legal system, universities and the state bureaucracy. ${ }^{22}$

According to De Jong, one prerequisite for the pillarization of Dutch academia the centralization of the university system - was put in place in 1815, when the Higher Education Act was passed which ensured that the universities would not go back to the earlier regional status they had had in the republic. This meant that now three state universities were created, at Groningen, Utrecht, and Leiden, Amsterdam being added to the list in 1876, though not as a state but as a city university. Usually, the foundation of the private Free (orthodox Protestant!) University in Amsterdam in 1880, followed by the Catholic University at Nijmegen in 1925, are seen as the

\footnotetext{
${ }^{20}$ In his speech at the 346th dies natalis (anniversary) of Utrecht University in 1982.

${ }^{21}$ Blom and Talsma give an overview of the most recent literature on the subject, where gender as an analytical category has not yet been given serious attention.

${ }^{22}$ De Rooij writes that the state could be seen as the "liberal pillar" which had its "constituency" in the public sphere: the universities, law courts and public bureaucracy (Rooij 2002, 145).
} 
material outcome of pillarization in higher education and research, the state universities representing the liberal pillar. ${ }^{23}$ According to De Jong, however, the three state universities were in the long run also segmented according to the main pillars. In the academy this meant that from the very first time a protestant government ruled, in the 1880 s, political and religious affiliation played a role in the appointment process not just for the Board of Curators (the administrators of the university), but also for the academic personnel in so far as they were appointed by the "crown" (state): the professors and senior lecturers. The result of this was the installment of a system of equal representation of religious groups in the universities.

This means that social (religious) considerations and not scientific qualifications have often played a decisive role in appointment procedures of scientists, even though these considerations were never mentioned publicly, or at least were not recorded in the dossiers that have survived. Discussion of any requirements for political, religious, and sexual conformity cannot be traced in the documents. They record only scientific qualifications, supplemented occasionally with a note on age or didactic requirements. De Jong concludes: "Whatever has been said about political background, religious conviction, sexual preference, social behavior, and whether these factors have been obstacles, has not been documented." He goes on to say that the process of pillarization happened at the expense of some social groups, such as women. In his words: "no ... female faculty and no persons to the left of liberal" were appointed during this period (Jong 1982, 32).

This is quite a revolutionary conclusion to be drawn by a respectable church historian and a high representative of the academic system in the Netherlands. The myth of meritocracy in science is so strong that it often eludes criticism and prevents serious discussion of the relation between science and society, even historically. But De Jong's conclusions are generously supported by archival sources dealing with the appointment of women faculty at Dutch universities in the same period under study. Particularly interesting in this respect are the files of 28 "crown appointments" (the female professors and lecturers [lectoren] appointed by the state) in the archives of the Ministry of Education, Culture and Science. The files are all of women born before 1903 and appointed between 1883 and 1964: 9 full or regular professors, 7 special or irregular professors and 12 senior lecturers or assistants.

In line with De Jong's conclusion that between 1876 and 1939 women were not even considered for appointments to professorships in state universities is the fact that the first full female professor in the Netherlands, the pediatrician Cornelia de Lange, was installed in 1927, at the University of Amsterdam, which at that time was still a city university, appointments being done by the city council. Amsterdam was considered a "red" city, and its council broke the ice by appointing both women and

\footnotetext{
${ }^{23}$ The Free University and the Catholic University at Nijmegen were for the most part state-subsidized universities. The boards of these universities selected the professors to be appointed by the crown. In Amsterdam, which was also largely state-subsidized, professors were selected by the city council, even if the actual appointment was done by Royal Decision (the Minister of Education, Culture and Science).
} 
socialists (and even communists) to university positions already before World War II. And not just De Lange, six of the nine full female professors in our files were at the University of Amsterdam. The files of the three other female professors who were appointed to a regular chair at one of the state universities show that this happened in all cases after 1945, and only after they had reached the age of retirement. ${ }^{24}$ In all cases, the women had been lecturers for several decades. One of them succeeded her deceased husband, a full professor in 1929, but with an appointment as a lecturer; she was appointed professor only in 1960 at the age of $66 .{ }^{25}$

The fact that Johanna Westerdijk in 1917 and a few other female professors before World War II were appointed at state universities does not contradict De Jong's findings; rather it underlines the importance of the distinction between full and extraordinary professorships. In comparison with a regular (or full) professorship, "extraordinary" or irregular professorships were poorly paid, part-time positions, reserved for people who earned their living elsewhere. This type of professorship was created to strengthen the ties between science and society, and to make room for areas of expertise that had not yet been part of the university curriculum. Irregular professors had the jus promovendum, and were members of the faculty and senate, but they lacked the power to vote in these decision-making bodies. Most women, then, were appointed only to irregular positions at these universities even if they were excellent scholars, who in some cases had developed whole new fields of study or developed and run major institutes. The fact that they were women, however, limited their appointments to the status of "extraordinarius" or irregular professor. That there were excellent women scientists in the pre-war period who did not come into positions according to their merits is also shown by the many female scholars who ended long and distinguished careers still in positions of senior lecturers.

The conclusion to be drawn is that the archives reveal a strong pattern of vertical segregation, which kept women in subordinate positions well into the 1960s, and which may in part be explained by a Dutch version of women's exclusion, namely as a by-product of pillarization as the Dutch system of dealing with social and religious difference. Though outwardly the three state universities were secular or religiously neutral institutions, this neutrality was assured only by a subtle system of equal representation of religious difference, which did not allow for the systematic inclusion of other differences, such as gender. As we have seen, the few women who held faculty positions were either appointed at the city University of Amsterdam, or were irregular professors without the power to make decisions. Given the strength of pillarization and its long endurance, this may well have contributed to the Dutch case (as the worst case).

\footnotetext{
${ }^{24}$ Professors were the only group of professionals who were allowed to remain in their jobs until the age of seventy.

${ }^{25}$ These statistics are drawn from the following archive: Algemeen Rijksarchief, 2 afdeling, 's-Gravenhage: Ministerie van Onderwijs, Kunsten en Wetenschappen: Personeelsdossiers Rijkspersoneel t/m geboortejaar 1903. Also Bosch 1994.
} 
Not just "first women in" but "exceptions to the rule": the case of Antonia Korvezee

All women who succeeded in getting an appointment were exceptions to De Jong's rule of "no female faculty." In each case, particular decisions were taken concerning a particular woman. Thus, in some cases, such as Westerdijk's, an influential man could play a supportive role, but influential men could also block a woman's career. In some cases, the state Ministry played a positive role, encouraging faculty boards to appoint a woman; in other cases the Ministry used its influence in a negative way, not even considering women for positions as professors. This whimsicality is painfully illustrated by the case of Antonia Korvezee (Jong 1988).

Antonia Korvezee (1899-1978) is remembered mainly as the first woman to become professor at the Technical University at Delft. This presentation tends to hide the complex and painful process of women's integration into science behind a rosy image of progress and increasing democratization. Those who remember her this way give her both too much and too little credit. Too much because she was appointed only irregular professor, and too little because to celebrate her as the first female professor at Delft downplays her scientific contributions to the field of theoretical chemistry and nuclear research.

Korvezee started her career at the Technical University in 1922 as an assistant in the department of analytical chemistry. Two years later she switched to physical chemistry to study with F. E. C. Scheffer and took her Ph.D. in 1930. She then went to Paris to work in Marie Curie's laboratory where she stayed for two years, partly on a French stipend, partly at her own expense. In 1938, she was appointed head assistant at Delft, where she was also admitted as an unpaid private lecturer to teach in the new field of radioactivity. In this period her name was put forward twice for a professorship, unsuccessfully. In 1948, her department proposed to the Minister of Science that she be appointed senior lecturer. This appointment was supported by pointing out that her appointment as head assistant had not "taken stock of the special scientific merits of Miss Korvezee, nor of her longtime experience that determines the value of the tasks she performs." She was passed over for a professorship a third time in 1953 when her teacher Scheffer was retired. As compensation, her department requested that the Ministry appoint her to an "extraordinary" professorship. She was said to be too "theoretical" and lacking the managerial skill required for a regular full professorship. This time the Minister's reaction was irritated and sharp - although sharper in the margins of the letters where he recorded his reactions than in the final draft sent to Delft. In his letter to the Delft department, the Minister stated that an irregular professorship would not be proportional to her extraordinary merits. The following correspondence between University and Ministry ended, however, in a decision to have her appointed to an irregular position. It made her the first female professor in Delft, indeed. However, as a consequence of the appointment, she had to leave the lab where she worked for thirty years and move to another. Her working days rapidly drew to a close after the move. At the end of the 1950 s, she was overtaken by fatigue (either from years of discrimination or from 
radiation poisoning) from which she never recovered. The under-recognition of Antonia Korvezee in historical studies of Dutch science continues today (Willink 1998); she is remembered nonetheless in an Antonia Korvezee Equal Opportunities Award that was established by the Technical University in 1989.

\section{Are there Historical Arguments for a Dutch Case?}

The question now is whether there are historical arguments for a "Dutch case" in the sense that there was something unique in Dutch culture or science that has put in place barriers not found in other countries. Looking at the patterns of women's participation in the sciences in the world, the Dutch case does not seem particularly unique. Just as other countries have produced their own Clarkes and Maudsleys, the Netherlands spawned Cox and Winkler to preach ruin in the face of women's aspirations to higher education. Just as elsewhere, Dutch women scientists endured horizontal and vertical segregation, and just as elsewhere the two cultures split along the lines of gender. And even if there was no formal quota system for women students in the Netherlands, their "invasion" was stopped at 20 per cent.

But if the gender gap may have been somewhat wider and the numbers of women making a career in science somewhat lower than elsewhere, a first explanation is always seen in Dutch women's unique weak position in the labor market in general as compared to her European and American sisters. ${ }^{26}$ Sometimes Dutch neutrality during World War I is mentioned as its cause, or the Netherlands' slow industrialization, but most often a specific Dutch brand of Protestantism is blamed, which in its strong emphasis on motherhood ideals ties women to the home more than in other countries. ${ }^{27}$ This explanation, however, seems to arise from a dichotomy between religion and modernity, and tends to ignore the importance of medical and biological theories which were invented as an inseparable part of Enlightenment thinking, and which legitimated the separation of the public and the private spheres in the nineteenth and twentieth century. Indeed, what about the role of doctors, psychologists, and pedagogues in constructing an over-demanding motherhood, not just in the Netherlands but in the whole Western world? Moreover, compared to other European countries, the Netherlands seems not to have been exceptionally protective towards women or mothers in its labor legislation (Bock 2002). Just as in other countries laws were passed - sometimes earlier, sometimes later - regulating (paid) maternity leave, night work, or equal pay. And just as in other European countries a breadwinner income came to be the rule, which was further refined in the income tax and welfare system. According to Plantenga, the main reason for Dutch

\footnotetext{
${ }^{26}$ Comparative historical figures of women in science in European countries and the United States, let alone countries in other parts of the world, do not exist.

${ }^{27}$ Plantenga checked all these explanations: slow industrialization, poverty, or neutrality during World War I. She concludes that it was the good economic situation, a high productivity rate, and pillarization that account for Dutch women's low participation in labor (Plantenga 1993).
} 
women's low labor participation was an economy that allowed many Dutch couples to live up to the ideals, thereby strengthening the ideology of women as not available for or capable of serious labor. We should add that this economic affluence of the Netherlands was due to its colonies, which before World War II contributed more than 13 per cent to the national income (Rooy 2002, 212).

This is not to say that religion did not play a role, but a different one than presumed, and as even more specifically Dutch, namely as pillarization. As we have seen, religion comes in as an important organizer not only of social institutions, but - quite unexpectedly, also of state institutions, such as state universities. ${ }^{28}$ The pillarization of academia for a long time seems to have influenced patterns of appointment, preventing women from being included on an equal basis.

Another, rather paradoxical outcome of the pillarization of the university system may be the absence of a fully differentiated university system which would have allowed women the privilege of different routes towards higher education or a career in science. Amsterdam became the only exception to the rule that women were not normally involved in the selection of university positions. Related to this may be the absence of women's colleges, which emerged in many other countries. As Rossiter has shown, women's schools and women's colleges have been important paths through which women would enter higher education and science. Moreover, in coeducational schools there were several patterns of segregation, hierarchical segregation being more rigid than territorial segregation. In a "women's institution" women had at least a fair chance to become professor. In fact, only Westerdijks laboratory seems to have functioned as an almost all female institution, and as such has produced more women scientists then anywhere else in the Netherlands.

\section{Part II. Dutch Women in Science: A Contemporary Perspective on "the Dutch case"}

\section{Anneke Levelt Sengers: a narrow escape from the Netherlands}

In 1963 the physicist Anneke Levelt Sengers left for the United States, together with her husband, Jan Sengers, a chemist. Looking back later, Levelt said she was convinced that a career in science would have been impossible had she stayed in the Netherlands because of the complete lack of understanding for working mothers (and the absence of childcare) and because of the general negative attitude toward women scientists: "In the Netherlands I heard the doors shut softly in my face when I was

\footnotetext{
${ }^{28}$ Plantenga also points to pillarization as a factor in Dutch women's labor position, claiming that the vertical segmentation of society was strengthened by lessening the horizontal segmentation of social class. Therefore, within the pillars a consensus could more easily be forged on the gendered division of labor.
} 
married and pregnant." 29 Her concerns seem warranted. She grew up in an unusual family - her father was a chemist and her mother a physicist - but it was really thanks to her own efforts that Anneke Levelt took up academic studies. Her mother was completely absorbed in raising her ten children, and when family finances were strained by the war, it was self-evident that her brothers would take up academic studies, not Anneke. This challenged her to apply for state funding. Upon finishing her doctoral exam, she decided to do a Ph.D. in the Van der Waals laboratory under the guidance of Professor Michels, whose wife had earned a doctorate at his lab and a cum laude promotion, which had almost been a media event in 1937 since she was a mother of four. As Levelt's position at the lab did not become stable, she left and spent a postdoctoral year in the United States. When she returned with four published articles, no one except her future husband seemed to notice, and they decided to leave the Netherlands. Shortly before the couple left, her husband was offered a job as lecturer at the University of Nijmegen - it was, in fact, Levelt's position.

At the National Institute of Standards and Technology in Gaithersburg, Maryland, however, there were no objections to her wish to combine motherhood and work, if she adhered to normal standards of productivity. Of course it was not an easy life with four children and a career, but Levelt did become a successful scientist who received high awards for her work on the critical phenomena of liquids (steam). She eventually became a member of the US National Academy of Sciences, the Academy of Engineering in the USA, and one of the very few female corresponding members of the Royal Dutch Academy of the Sciences.

\section{The success of women's studies: another Dutch case}

Five years after Anneke Levelt left for the United States, Joke Smit, a senior lecturer of English at the University of Amsterdam published the article "Het onbehagen bij de vrouw" (The discomfort of women) (Kool-Smit 1968). Like Betty Friedan's Feminine Mystique, it was a seminal article that eloquently protested against society's expectations that women become housewives, a group that Smit ironically referred to as a "herd of Hoover cattle." It sparked off the second wave of feminism in the Netherlands. Within a few years a mass movement came into being consisting of many different organizations and groups (Meijer 1996; Ribberink 1998).

As part of the new activism in 1974, women's groups at several Dutch universities assembled to discuss women's minority position in the universities, which was first and foremost attributed to "sexist science." Following these discussions, women's studies groups in many disciplines were formed which pressed for research and teaching from a feminist perspective. In Amsterdam this resulted in the appointment of the first lecturer of women's studies in the political and social sciences faculty

${ }^{29}$ The information on Anneke Levelt Sengers is based on one of four interviews which Elma Drayer did for the AWT backgound study (Drayer 1999 in Bosch et al. 1999). 
(department) in 1977, although for many years to come many women were contributing to the new learning as students or as volunteers. At the end of the 1970s and the beginning of the 1980s the first women's studies journals were founded and a national organization was formed to provide a platform for adherents of women's studies, the Netherlands Association of Women's Studies which exists today as Nederlands Genootschap Vrouwenstudies (NGV). ${ }^{30}$

From then on women's studies (also known as women's and gender studies or gender studies tout court) in the Netherlands have developed impressively. From its start, women's studies attracted government funding, much of it due to its claim to solve the problem of under representation of women in academia. Saskia Grotenhuis, who played a central role in the organization of Dutch women's studies, wrote on the occasion of the first fifth anniversary celebration of the Dutch Tijdschrift voor Vrouwenstudies (Journal of Women Studies, recently renamed Journal of Gender Studies): "The marginal position of women in the universities and in science, the inequalities between women and men, were an important reason for the development of women's studies in the 1970s" (Grotenhuis 1988). Indeed, when equal opportunities policies (in the Netherlands called "emancipation policies") became an issue in the Ministry of Education, Culture and Science at the end of the 1970s, the first action by the minister was to support the appointment of women's studies teachers and coordinators at almost all universities. ${ }^{31}$ In 1985 an advisory group (VBEO) was installed by the government to stimulate women's studies in the academy and scientific research, to define priorities for women's studies research and to help divide a sum of F 4,800,000 (about E 2,000,000) to promote women's studies research across the disciplines through grants. ${ }^{32}$ At about the same time women's studies got a formal representation in the National Organization for Scientific Research (NWO) in order to promote the funding of women's studies. ${ }^{33}$

These measures resulted in a stream of Ph.D. theses in women's studies at the end of the 1980s. At the same time chairs and departments in women's studies were founded, resulting in a comparatively strong institutionalized field. In 1995 there were about 20 full professors in women's studies, 13 associate professors, and 89 assistant professors though not all in a full time position (Lasthuizen 1995; Jansen

\footnotetext{
${ }^{30}$ The most important journals were: Socialistisch-Feministische Teksten (1978), the Tijdschrift voor Vrouwenstudies (1980) (Journal of Women's Studies, today Journal of Genderstudies) and the Jaarboek voor Vrouwengeschiedenis (Yearbook of Women's History that still exists today).

${ }^{31}$ In 1979 the first white paper on gender equality in education came out. The first measure on equality in higher education was to introduce women's studies at the universities to enhance women students' motivation. The Minister was prepared to finance a women's studies coordinator on a 50 per cent matching basis, and one chair (for all universities) in the field of emancipation or equal opportunities oriented research (Mottier 2002; Bosch 1999, ch. 1).

${ }^{32}$ For the division of this money the Stimuleringsgroep Vrouwenstudies- en Emancipatie Onderzoek (STEO) was founded.

${ }^{33}$ Dwarsverbandcommissie Vrouwenemancipatie-onderzoek bij NWO, later WerkverbandVrouwenstudies en Emancipatie Onderzoek (WVEO).
} 
1996). The jewel in the crown is the Dutch Research School for Women's Studies (NOV), a national scientific and educational network that was founded and recognized by the Royal Academy of the Sciences in $1995 .{ }^{34}$ In this school women's studies researchers cooperate in five interdisciplinary research programs. Also the NOV offers a Ph.D. program in women's studies. Due to the strong international orientation of Dutch women's studies, the Women's Studies International Europe (WISE) was organized in 1990 and the foundation of the European Journal of Women's Studies set up its administrative centers at the University of Utrecht.

At the beginning of the 1990s the success of women's studies was widely advertised nationally and internationally. In an inventory of about 300 women' studies scholars the fact that 150 of them had fixed positions provoked the remark: "For a young scientific field, developed in a period of budget cuts, not a bad performance" (Lasthuizen 1995, 5). An interview entitled "The Dutch Case" with Margo Brouns, who did the first large scale evaluation of women's studies, appeared in the first issue of the European Journal of Women's Studies (Brouns 1988/1990; Davis and Grünell 1994). Brouns attributed the success of women's studies to a mixture of governmentsupported institutionalization and a kind of Dutch tolerance and pluralism in forming academic disciplines. Willie Janssen, who pondered the question in 1996, attributed the successful development of women's studies to a stubborn adherence to the principles and policy of integration and autonomy, or "the double track." She claimed that even though the pressures on integration have been and are always strong, women's studies as a field can only survive on an independent basis, even if integration is an important goal (Jansen 1996).

\section{Reorganizations and Cutbacks}

"The success of women's studies has a shadow side as well." Kathy Davis wrote these words focusing mainly on the internal divisions and conflicts she perceived within women's studies in the Netherlands. However when she added, "Women's studies in the Netherlands may be flourishing, but the position of women in the academy couldn't be worse," it was clear that the "shadow side" also referred to something else (Davis 1996). This truth gained ground in the beginning of the 1990s, posing a kind of counter narrative to the success story of women's and gender studies. Even though the number of women students had increased tremendously (though not yet in an evenly distributed way), and although women's studies had taken a firm stance throughout the institutions, the position of women academics in general had even deteriorated as compared to twenty years earlier. The news became also internation-

\footnotetext{
${ }^{34}$ The Secretary of the NOV is University Utrecht; its director, Professor Rosi Braidotti, who chairs one of the largest women's studies units in the Netherlands, in the Humanities Faculty, UU (see www.let.uu.nl/ nov/).
} 
Table 5: University Students in the Netherlands 1970-2001

\begin{tabular}{lccc}
\hline & Total & Female & \% Female \\
\hline $\mathbf{1 9 7 0}$ & 102,219 & 29,995 & 19.8 \\
\hline $\mathbf{1 9 7 5}$ & 120,134 & 45,838 & 25 \\
\hline $\mathbf{1 9 8 5}$ & 166,636 & 61,381 & 36.8 \\
\hline $\mathbf{1 9 9 5}$ & 176,096 & 80,838 & 45.9 \\
\hline $\mathbf{2 0 0 1}$ & & & $49 \star$ \\
\hline
\end{tabular}

Source: Bosch 1999; ^ Mottier 2002.

ally known through several publications in the beginning of the 1990s (Hawkins and Schultz 1990; Hicks 1991; Lie et al. 1994; Rose 1994, 102) (see Tables 5 and 6).

According to many this loss in an age of feminist agitation and emancipation policies is due to reorganization and cutbacks in Dutch higher education and science in the 1970s and 1980s (Mottier 2002; Bosch et al. 1999; Beekes 1991; Ministerie van Onderwijs, Cultuur en Wetenschappen [Ministry of Education, Culture and Science] 1979, 1981, 1982, 1985, 1986). Even if universities had been willing to make changes with respect to women academics, so it is reasoned, they could not succeed because of the many intrusions from the central government in The Hague. From the beginning of the 1980s, there were major changes in the academic and scientific landscape. One important change was the shift in funding research due to the desire for more democratic control and better quality. Increasingly, research funding which had earlier been provided and divided primarily by the universities - had to be earned through competitive application and peer review evaluation by the Netherlands Organization for Scientific Research (NWO). Also a system of

Table 6: Percentage of Women (in full time equivalent) in the Three Top University Ranks in 1970, 1980, 1988, 1990, 1995 and 2000

\begin{tabular}{lcccccc}
\hline Rank & $\mathbf{1 9 7 0}$ & $\mathbf{1 9 8 0}$ & $\mathbf{1 9 8 8}$ & $\mathbf{1 9 9 0}$ & $\mathbf{1 9 9 5}$ & $\mathbf{2 0 0 0}$ \\
\hline Professor & 2.7 & 2.2 & 2.1 & 2.6 & 4.2 & 6.3 \\
\hline Associate Prof. & 9.4 & 8.9 & 4.6 & 5.7 & 7.1 & 10.7 \\
\hline Assistant Prof. & 11.8 & 15 & 15.1 & 15.5 & 18.2 & 22.3 \\
\hline
\end{tabular}

Source: Hawkins and Noordenbos 1990; Noordenbos 1994-95; WOPI 1995; WOPI 2000. 
evaluation (or visitation) of university faculties was installed. Another important reorganization was an effort to restrict the number of professorships and a more general restructuring of the ranks. Consequently, the academic career track was changed from an individual promotion path (or tenure track) to a system of fixed positions (formation). Individuals were not automatically promoted anymore on the basis of merit and/or seniority but had to apply each time a position became available (which was not very often).

Especially this last reorganization and the underlying budget cuts were responsible for blocking progress with regard to women in academia. At the end of the 1980s, it became clear that although the participation of women academics had grown slightly, the percentage of women in higher positions of associate and full professor had actually dropped. Noordenbos and Hawkins in an evaluative study in 1990, argued that the whole operation started from the gender-blind assumption that something had to be done to reduce the number of professors, who held 50 per cent of the positions. That women held only about 2 per cent of the chairs was overlooked. They also drew attention to the fact that after the operation 85.6 per cent of the women in academia held the rank of assistant professor; for men this was 53.4 per cent. Men, therefore, had a much greater chance than women to become professor or senior lecturer (Hawkins and Noordenbos 1990).

\section{The Growing Gap between Bureaucrats and Scientists}

Cutbacks and reorganizations in the academic system help to explain the poor showing of women in science, yet they are not the whole story. If equality for women had been an issue of importance for science administrators in the rank and file of the university, that would have influenced how reforms were carried out. In the 1980s, however, if the university management considered gender inequality at all, it was defined as a "woman's problem," either a social problem outside the purview of the university, or a biological problem. The center of focus was women's capacity of motherhood and all that entailed: lesser ambitions and the belief that it was impossible for women to give full time to their jobs. Even if in the course of the 1980s "emancipatie-commissies" (Equal Opportunities Committees) were formed at many universities - most often linked to the democratic structures of the university, and on a voluntary basis - these were supposed to deal with childcare, parental leave, or measures to empower women individually. At the end of the decade the Ministry of Education, Culture and Science advised universities to install a system of affirmative action and defined target figures. At the same time the first university employed equal-opportunity officers to support activity in the realm of gender-conscious human resources management.

The national policy of university reform increased the power of university administrators and decreased the traditional academic liberties enjoyed by faculty. These developments were pushed further with the move toward further privatization 
of the universities after 1988, which was concluded by the Law on Modern University Administration (MUB) in 1997. Scientists increasingly began to strengthen their claim to manage and select their own scientific personnel in order to protect themselves against too much managerial intrusion. This they did by keeping a tight rein on their professional right to define scientific quality as an internal matter or a matter of peers, and shielding recruitment and selection procedures from the hands of bureaucrats. While managers and administrators increasingly adhered to the advantages of professional human resources management to support the move towards autonomy, scientists preferred the mechanisms of the old-boys' network. Actually, as professor of history Chris Lorenz remarked, the professors did not even protest the gradual invasion of the managers because they knew their recruitment and selection methods were anything but fair, but they wanted to keep things as they were (Lorenz 1993). ${ }^{35}$ The development of a more socially responsible science that emerged after the war and accelerated in the 1970s resulted in conceptions of a university that depended for its accountability on a growing bureaucratic apparatus in the next two decades. In the 1980s discourse about "critical science" was exchanged again for discourse about the principles of academic freedom that stressed the scientists' need for autonomy in defining scientific quality.

Women lost out twice in this situation. Recruitment through the old-boys' network had always favored applicants already in the system or new applicants who looked and performed very much like the recruiters. Women scientists, in not looking or behaving like the "old boys" found this to have a negative influence on recruiters' perception of their abilities (Van Vianen 1997). Secondly, equalopportunity policies and affirmative-action measures were resented as an intrusion. As a result these policies became marginalized to personnel departments within the central bureaus of universities (Braat 1991). Equal-opportunity policy makers were kept at a distance from the faculties and were allowed to deal mostly with social measures, such as day-care centers or women's personal career plans. These policy makers were not concerned, however, with the core activities of the university, that is, research and teaching, and the criteria used to assess quality. The gap between bureaucrats and scientists explains why even at the progressive University of Amsterdam, affirmative-action measures (such as the rule that in recruitment procedures all women who applied should be considered, or that a woman who was qualified for a job should be appointed even if there was a "better man") collapsed under collective protest from professors. An in-depth analysis of five controversial recruitment procedures under this affirmative-action recruitment regime, in order of the Ministry of Social Affairs, shows how affirmative action and "women" tout court came to symbolize the very antithesis of scientific quality, and how in comparing the qualifications of male and female applicants, the female applicants were generally seen

\footnotetext{
${ }^{35}$ This essay was signed by thirteen other scientists who commented upon the developments in the media turning it into a kind of manifesto.
} 
as inadequate because in all cases the male's profile in the course of the procedure became the standard profile (Verhaar 1991). ${ }^{36}$

\section{Equal Opportunities, Gender Studies and Female Scientists: Divided Interests and Perspectives}

Except for the above mentioned structural developments in the 1980s and 90s the failure to increase the number of women scientists in academia in the 1970s and 80s had also to do with the divided interests, perspectives, and powers of the equalopportunity policy makers, the gender-studies scholars, and the women scientists. Indeed, the situation holding women at bay in American sciences described by Londa Schiebinger in an article in Osiris seems to hold for the Netherlands as well: "One reason [for the continuing inequalities women in science] is the tragic divide between three increasingly self-contained groups of experts: those who fashion and fund intervention programs designed to increase the number of women in science; historians and philosophers of women and gender in science; and scientists" (Schiebinger 1997, 202). In the same issue, Evelyn Fox Keller describes hostility and an almost-unbridgeable gap between gender and science experts on the one hand and women scientists on the other (a gap related to the differences between feminists and other women), and says her task is "to go beyond assumptions either of a natural commonality or of an entrenched opposition between women scientists and feminist analysts of science" (Keller 1997, 16).

That the gains for academic women in the Netherlands were contained within women's and gender studies units and even ran counter to the situation of women scientists in other disciplines began to be noticed in the second half of the 1990s, especially among gender studies scholars. Thus, Willy Jansen, an anthropologist and professor in women's studies, observed in an overview on women's studies in the Netherlands in Women's Studies Quarterly in 1996:

As in other countries, Dutch universities suffered from the tightening of budgets for higher education. During reorganizations, university staff was laid off on the basis of "last come first out." This rule hit women harder than men. Departments had tried to hire more women over the last decade, but these newcomers suffered most. . . . As a result, the already small number of female teaching and research staff was approaching zero in many departments. The establishment of women's studies centers and the creation of women's studies chairs (often part-time and temporary) enabled universities to save face and keep their best employees. Also women's studies units used the diminishing female staff in general as an argument to gain or maintain their place at the university. This partly

\footnotetext{
${ }^{36}$ The University of Amsterdam did go on to develop effective emancipation policies. According to Portegijs, the Amsterdam University's active stimulation program, based upon a special fund, has been the exception to the rule of ineffective university policies (Portegijs 1998). The percentage of female professors at the UVA was 8.3 on December 31, 2000 (WOPI 1999).
} 
explains the curious situation mentioned above that the Netherlands belong to the countries with the lowest percentage of female university staff in general, but nevertheless has a fair number of women's studies posts. For instance, of all the professors at the university, women make up only 3.6 per cent. But of the 148 female professors in the Netherlands in 1995, 17 are in women's studies, that is 11.5 per cent. Not bad for a new discipline, but we would prefer a fair representation of women in the highest echelons in all discipline, not just women's studies. (Jansen 1996, 332-333)

Jansen implicitly states that women's studies profited from the cutbacks at the cost of women scientists. Kathy Davis is more critical in formulating the same process: "women's studies has increasingly taken on a token function for a university more interested in cutting costs than eliminating gender inequalities" (Davis 1996, 188). Davis also gives an underlying explanation for this development as the general lack of interest on the part of women's studies departments:

Academic feminists in the Netherlands have been wary about having women's studies equated with the overall position of women in the university, arguing and quite rightly - that women's studies has a different focus. Feminist scholarship is concerned with the analysis of "gender" rather than with emancipation issues. Moreover, many academic feminists have their hands full carving out a niche for women's studies without having to sit on hiring committees or tackle the affirmative action policies of their universities. In addition, some feminist scholars are critical of affirmative action for theoretical reasons: it doesn't "get to the root of the problem" or it "reifies rather than deconstructs gender dichotomies." (Ibid., 187)

Her view is sustained by Mottier who in her national report on The Netherlands underlying the recently published Helsinki Report (Rees 2002) - remarks that in the 1980 s only about ten gender studies researchers (out of more than three hundred) were interested in questions concerning women, gender and science (Mottier 2002). Saskia Grotenhuis ten years earlier had argued that women's studies was interested in "all women" and not only academic women who formed a very small if not elitist group (Grotenhuis 1988). Moreover, the concept of equality became a contested concept and "equality or egalitarian feminism" was considered by some to be a lesser kind of feminism that lived by superficial "sex counting" and "fixing women's problems."

The distance between emancipation policies and related research has been an unnoticed but persistent feature of women's studies in the Netherlands. By favoring a conviction that women's inequalities in science were epistemological rather than social and cultural, and demonstrating a certain disdain for the applied science of diagnosing and empirically investigating the relation between women, gender and science, or formulating and implementing gender expertise in academic policy, Dutch women's studies fuelled the idea that equal opportunities policies lay outside the core of university business. In so doing women's studies assessed the separation between science and society as well as the gap between scientists and bureaucrats. It 
was one aspect of their strategy to gain respectability in the academic or scientific world.

Because of this situation equal opportunities officers have often missed the insights from women's and gender studies regarding the complex relations between women, gender, and science. Lacking the necessary support and lacking power, their policies and programs for too long focused too much on "women as the problem in need of fixing," too little on the central role of science as a social process, and producing rather than reflecting gender relations. Too often they were "enclosed" in the bureaucratic section, most often in the personnel management department in the universities, far from the universities' core business.

Far into the 1990s, female scientists who were not in gender studies have more often than not turned their backs on the active politics of changing science and the position of women in science by gender studies specialists or equal opportunities officers. Their effort was to remain as much as possible invisible "as a woman" even if they sometimes profited from the effects of feminist activities. In contrast to the feminist professor Mieke Bal who declared she would rather be appointed "as a woman" than not to be appointed "as a woman," many female academics turned up their noses at positive action measures or affirmative action recruitment programs (Drayer 1999). It is only recently that female professors have organized the association, the Landelijk Netwerk Vrouwelijke Hoogleraren (LNVH). ${ }^{37}$

\section{Contemporary Arguments for the Dutch Case: Pillarization Again?}

The divisions between women or groups of women are noted because, although they are not unique, they may serve to explain the Dutch case - the relative large underrepresentation of women - as indeed again a Dutch case of pillarization. This suggestion is inspired by Margo Brouns' observations: "By subsidizing opposing religious or political groups, the state has traditionally ensured that all parties have their needs met - at least to some extent - thereby ensuring a kind of peaceful coexistence. This social tradition paved the way for the institutionalization of women's studies, which became in a certain sense just one more 'pillar' - albeit a small and relatively weak one" (Davis and Grünell 1994, 102). Though in the 1980s the Netherlands was already far into the process of de-pillarization, we can agree with the idea that the success of Dutch women's studies could be explained by the old system and mechanisms of pillarization. But, we should add, so can the failure of integrating women scientists in academia, as well as the rather unsuccessful integration of gender studies in the "regular" disciplines. The institutionalized segmentation of society on the basis of political or religious conviction is capable of recognizing and awarding albeit to a limited extent - the feminism of women's studies (which is based upon an

\footnotetext{
${ }^{37}$ The network has a strong commitment to equal opportunities policies. The first action taken was a letter to the Minister to promote the appointment of women professors.
} 
ideology and a "constituency"), but not "women" or "women scientists" as a group, and not gender as a category of political division. Pillarization may also explain the typical Dutch situation of women in science because of the role of elites. One aspect of pillarization is the central role of the elites of the pillars, representing the pillar as a whole. One could argue that women's studies in a way came to be seen as the elite of the "women's pillar," at least in academia, and so became representative of "women scientists" all over the university. Women's studies therefore could claim that what was good for them was good for "all women" in the university.

If we compare Norway and Sweden, we can see how important the cooperation of women's groups and women's interests is (Lykke 2001). But there is of course much more to learn from good practices in other European countries and the United States. For instance, Germany is doing visibly better than the Netherlands on the issue of women in science in the last few years. To learn from Germany's experience, we should examine how its equal-opportunity policies were organized and by whom, how women's studies developed, and the role of the federal state and universities in implementing principles and programs. Such an analysis would also give a more definite and well-founded answer to the question of the "Dutchness" of the Dutch case.

\section{Turning the Tide ${ }^{38}$}

In 1997, almost a hundred years after the public debate concerning women in higher education and almost fifty years after Dutch academic women documented their accomplishments in a book of statistics, the academic world was shocked into action by the Swedish study, "Nepotism and Sexism in Peer Review." Although the study proved the existence of a gender bias in the peer review process of the Swedish Medical Research Council in only one particular year, it suggested a wider pattern of discrimination in the sciences. The study seemed to distill the essence of what had been suggested by numerous "anecdotal" answers to the question: "Women Scientists: Why so Few?” (Rossi 1965).

In the Netherlands, the Nature article caught the attention of the media as well as NWO, the Advisory Council for Science and Technology Policies (AWT), and the Ministry of Education, Culture and Science. NWO immediately did an analysis of the success rates of men and women in its programs and concluded that on the basis of the available figures no conclusion could be drawn about possible gender bias in the peer review system. However, the findings did indicate that very few women applied for funding. NWO cooperated also in a more in-depth study into the peerreview process ordered by the Ministry of Science and Education and undertaken by the Netherlands Association for Women's Studies (NGV). This study revealed no hard

\footnotetext{
${ }^{38}$ The metaphor of the "rising tide" was used in Great Britain in the title of an influential report (Committee on Women and Science, Engineering and Technology 1994).
} 
evidence of gender bias, but it did show that the qualifications of men and women tended to be evaluated differently (Brouns and Scholten 1999; see European Commission 2000, 34-35). An independent study showed that few women applied for grants at NWO because of the low numbers of female professors and the unequal distribution of women across the disciplines. The study showed that the underrepresentation of women is greatest in those disciplines where funding is greatest - in the natural sciences (see Table 7) (Noordenbos 1999).

The Swedish study also fuelled interest in the "Law on Equal Representation of Women in Leading Positions in Education," which passed in 1997 after years of discussion and lobbying by the national platform of Equal opportunities policy makers in science and higher education (LOEKWO) and others. Although the law was aimed at women in secondary school administration, the Minister charged universities to set target figures for women in university positions and make plans for how to reach those targets. The Minister also distributed the results of a study that documented women's lack of advancement in universities. The study clearly demonstrated that due to the immobility of academic personnel, women largely did not get promoted. It concluded that if nothing changed, the under-representation of women would worsen. One of its recommendations was to return to the system of a career track for academic personnel based on performance (Portegijs 1998).

This report and various statistical publications described the situation of women in faculty positions (cf. Balen and Fisher 1998). By the year 1995, women represented 45 per cent of all university students in the Netherlands (up from 17 per cent in the 1950s). In the 1990s, the percentage of women earning doctorates was 23.65 (up from 4.1 in the 1970s). This growth at the undergraduate and graduate levels was not reflected in academic staff. Among Dutch professors, women were still heavily underrepresented with 5 per cent of 2,445 full-time positions in 1998. For associate professors (fixed positions not automatically leading to professorships) the same was true with 7.5 per cent women. Female assistant professors fared only a little bit better with 20 per cent (13.8 per cent of them in temporary positions) against 80 per cent men (8.7 per cent in temporary jobs) (Bosch 1999). The figures for women in university boards as deans or in administrative positions in the KNAW or NWO drew attention to the adverse effects of the modernization process on the position of women (see Table 8). Only then did it become clear that the Netherlands's record lagged far behind that of other countries, and that the percentage of Dutch women professors was lowest in the world except for that of Botswana which had 0 women professors. $^{39}$

The heightened attention to the subject of women in science generated more reports. The Advisory Council for Science and Technology Policy commissioned a background study to the LOEKWO, posing the question "why so few?" (Bosch 1999). The history of the development of Dutch science over the past twenty years

\footnotetext{
${ }^{39}$ This information is from a table in Lie and Malik 1994. We have never liked this comparison for its roots in racist civilization theory.
} 
Table 7: Women in Some University Disciplines, 2001/2002 (percentages)

\begin{tabular}{|c|c|}
\hline Mathematics & 28 \\
\hline Informatics & 13 \\
\hline Physics & 18 \\
\hline Chemistry & 28 \\
\hline Biology & 48 \\
\hline Pharmacy & 56 \\
\hline Architecture & 31 \\
\hline Mechanical engineering & 6 \\
\hline Electrical engineering & 5 \\
\hline Medicine & 60 \\
\hline Dentistry & 50 \\
\hline Economics & 27 \\
\hline Law & 55 \\
\hline Psychology & 76 \\
\hline Pedagogy & 89 \\
\hline Political science & 41 \\
\hline Theology & 48 \\
\hline French & 79 \\
\hline English & 76 \\
\hline German & 68 \\
\hline History & 42 \\
\hline
\end{tabular}

Source: Ministry of Education, Culture and Science (Mottier 2002). 
Table 8: Membership of University Boards, Committees of Deans and Leading Positions in the KNAW and NWO

\begin{tabular}{lccc}
\hline & Total & Women & \% Women \\
\hline University Boards & 40 & 2 & 5 \\
\hline Committees of Deans & 135 & 3 & 2.3 \\
\hline KNAW & 43 & & 7.7 \\
\hline NWO & 65 & 5 & \\
\hline
\end{tabular}

Source: Bosch 1999.

and general gender theory provided some answers. The heart of the book was a plea for universities to develop broader, multi-dimensional definitions of scientific quality more in step with the multiple functions and forms of today's research, referring to Schiebinger's conception of "sustainable science" and Brouns' and Harbers' conception of science as taking place in the agora instead of on Olympus (Hoving 1999; Schiebinger 1997; Brouns and Harbers 1994). ${ }^{40}$ The study ended with a review of equal opportunities and diversity policies in academic and research institutions in other European countries and the United States and made five recommendations:

- To create extra chairs for women (like in Sweden)

- To enlist gender equality goals in the system of contract compliance between state and universities (like in Germany)

- To mainstream gender equality goals in all policies at all levels of universities and scientific institutions (like in the European Union and Germany)

- To integrate gender and diversity perspectives in all teaching and research plans

- To create a national advisory and expert center on women, gender and science to coordinate and stimulate research, and to develop and implement policies (Bosch 1999, ch. 5).

The AWT study was presented at a major conference on women and science in Amsterdam, 12 October 1999, organized by the NWO, the VSNU, the AWT and the VSNU. In several lectures references were made to the Swedish study and there was a report on inequalities for women scientists at the Massachusetts Institute of Technology (MIT 1999; AWT, KNAW etc. 1999). Both studies were the result not of actions by equal-opportunity policy makers or gender researchers, but rather by

\footnotetext{
${ }^{40}$ The book attempted to broaden the scope of diversity policies to stress the interconnectedness of gender with other axes of difference, such as ethnicity. In European, as well as in national policies regarding gender and science, there is still a very restricted view of gender, which implies and perhaps strengthens a definition of science as a "white" phenomenon.
} 
women scientists, and perhaps for that reason made such an impression. Both documents stressed that gender inequalities result not from one large organized cause but from a series of small and almost imperceptible differences in the treatment of men and women. Both documents evoked worldwide reactions on the website of Nature.

A sense of breakthrough was in the air. The President of NWO, Reinder van Duinen, referred to his own changed understanding of the gender issue in academia as a "paradigm shift" (AWT, KNAW etc. 1999, 93). In his opening speech, the Minister of Education, Culture and Science, Loek Hermans, offered praise and financial support for a program to promote 30 female assistant professors to associate professors. This program, named after the female Greek philosopher Aspasia, was to be implemented jointly by the Netherlands Organization for Scientific Research and the universities. Under this program, female assistant professors (or junior lecturers) could apply for funding of a four-year Ph.D. research project, or a two-year postdoctoral research project. The plan foresaw thirty Aspasia promotions in two groups of fifteen, the first call being in 2000 and the second in 2002.

A few months after the meeting at the Trippenhuis, the Advisory Council for Science and Technology Policy presented an advisory paper to the government (AWT-Advies 2000). This paper repeated some of the recommendations of the background study: to create extra chairs for women and to found a center for research and policy making with respect to women and science. Furthermore it recommended that the Aspasia Program be enlarged, a recommendation which was taken over immediately by the minister.

The Aspasia Program has proved to be an overwhelming success. At the first call, instead of fifteen, 68 women were promoted, bringing the percentage of female associate professors from 8.5 to 11 per cent. The large number of highly qualified applications alerted universities to the under-use of women's potential and gained enthusiastic support from the NWO-board (Bosch and Potting 2001). ${ }^{41}$ In addition, Spinoza awards were granted to the Australian Anne Cutler in 1999, E. F. van Dishoeck in 2000, and D.I. Boomsma in 2001. Both KNAW and NWO have appointed more women to their several boards and committees.

The increased interest in the multiple aspects of women in science can be seen in the case of the age criteria for applying at NWO and KNAW research programs which came before the National Committee for Equal Treatment by the NGV. ${ }^{42}$ The

\footnotetext{
${ }^{41}$ At the first call 31 women received grants from NWO and they were promoted to the position of UHD. In addition, universities promoted 37 women who were qualified as excellent, but could not be funded. Sometimes the universities funded the research project as well. On the second call 40 women received an Aspasia grant from NWO. It is expected that universities will also promote women who received good evaluations but did not get grants.

${ }^{42}$ The committee ruled that age criteria indirectly discriminated against women and should therefore be dropped or implemented on a differential basis. In a way the rule was a mixed blessing since the committee based its judgment on fertility statistics only, thereby implying that women's under-representation in science had a "natural" cause (Steen 1998).
} 
NGV added to its goal of promoting women's and gender studies, also women in science generally. Research in issues relating to women, gender, and science increased notably, and a few dissertations appeared on the subject (Balen 2001; Dekker 2000). In April 2001 the research school NOV organized a conference on the "Dutch case" and the national network of women professors (LNVH) held a conference dedicated to women professors. ${ }^{43}$

Whether these developments will turn the tide is still to be seen. Except for the visible increase of women as associate professors (due to Aspasia) there is still no progress. The most recent Arbeidsmarktmonitor (Labor-market monitor) for the academic sector has come up with figures that show (rightly or not) that the gap between men and women with respect to the chances they have to become professors has become even wider (Arbeidsmarkmonitor, 16-20). ${ }^{44}$ This was calculated on the basis of a comparison between student generations $(\mathrm{m} / \mathrm{f})$ and related age groups of professors (m/f). While men between 55 and 59 (who finished their academic studies between 1970 and 1974) had a 3.7 better chance than women to become professors, men between 40 and 44 have an even better chance: 5.5. The position of women's studies also proves less stable than the strong institutional position seemed to indicate. Although the National Research School passed the (international) visitation, and was recognized by the KNAW for another five years, locally the picture is much less promising. Many centers are based upon "special regulations" and integration of gender in disciplinary research and teaching has not been attained. ${ }^{45}$

Even the turnover of academic personnel expected in the near future due to the asymmetrical age curve is lamented without taking into account the many talented women who represent a potential which is still underused. ${ }^{46}$ An exception to this forms the report "Talent voor de Toekomst, Toekomst voor Talent" (A Future for talent, talent for the future) which fully integrated a gender dimension (Vucht Tijssen 2000). Many of its recommendations echoed earlier ones, such as to drop the system of fixed formation and instead turn to a career pattern based on quality and experience. Also - and now for the third time - it was recommended to install an expert center on Women in Science. The failure of this last initiative to materialize is, however, an ominous sign. More than a year after the Minister assigned the VSNU to make plans for such an institution in cooperation with NWO and the KNAW and

\footnotetext{
${ }^{43}$ The conference, "Iedereen hoogleraar?" (Everybody a Professor?), was held at the Trippenhuis in Amsterdam, May 302002.

${ }^{44}$ In the report a reservation was made about the possibility that men become professors at a younger age. This will probably be an important explanation for their findings.

${ }^{45}$ This conclusion can be drawn from the contributions to the conference "De IJkpunten geijkt" which was an assessment of the results of the large historical project financed by NWO between 1992 and 2002 on "Dutch culture in a European context" (Bosch and Hellevoort 2002).

${ }^{46}$ A typical example of the neglect of the availability of talented women in the face of the great turnover of academic personnel is the interview with the newly appointed president of the KNAW, Pim Levelt, a brother of Anneke Levelt, in the national daily paper NRC, 1-2 June 2002: "Talent wordt nu verspild" (Talent is wasted now). He focused only on "young scientists," mentioning women scientists only in passing.
} 
based upon the knowledge and experience in the field, a plan was put on the table that lacked vision as well as flesh and bones. Thereupon the Minister - all too easily - dropped the plan.

\section{Toward a Delta Plan for Total Equality in Dutch Academia and Science}

"Do something structural about the Dutch case," declared the newly appointed professor at the Faculty of Mathematics and Natural Science at the University of Groningen, Jeanine Olsen. ${ }^{47}$ Taking into account the good practices of countries such as Germany, Sweden, and "Europe" itself, one could name a few basic needs to confront the Dutch case. First, to develop a structural, multi-level national policy plan - a real Dutch Delta Plan - which would combine a stimulation plan for women professors (such as in Sweden), which is at all levels committed to gender mainstreaming (such as in European research) and which plays a central role in the management control cycle (or contract compliance) between universities and Ministry (such as in Germany). The plan should have a firm financial basis and make use of financial steering mechanisms (cf. Bosch 1998).

The commitment of this Delta Plan to gender mainstreaming at all levels of the scientific and academic process means the inclusion of all aspects of women, gender, and science into all institutions of science and education. The plan should target the integration of gender perspectives in research and education, the development of gender studies as an autonomous field of research, as well as equality issues (or issues of difference) in recruitment and selection of women scientists, the culture of science, the representation of science and scientists. The commitment to gender mainstreaming should also mean that the strategies and recommendations are always firmly connected to the different contexts of science. Last but not least, the plan should build into its basic principles a recognition of the interconnection between gender and other axes of difference, such as age and ethnicity. In Germany for this inclusive definition of gender mainstreaming the term total E-quality has been developed and connected to an award system for universities.

To succeed, such a plan would require a powerful structure to deal with the issue of women in science, for instance, a strong women and science unit connected to the National Association of Universities (VSNU), or a national steering committee in close contact with the most powerful players in the field, KNAW, NWO and the Ministry, as well as in "Europe." 48 Leaders in academic policy and research, gender (and science) researchers, equal opportunities policy makers, and women scientists should consult regularly and commit to an orientation on the recognition of

\footnotetext{
${ }^{47}$ Interview with Prof. dr. Jeanine Olsen (UK, personeelskatern, April 2001).

${ }^{48}$ The Helsinki report claims to have a Women and Science Unit in the Dutch Ministry of Education Culture and Science. While a few dedicated civil servants are dealing with the issue, it is little compared to the Women and Science Unit in the Federal Ministry in Germany, or in Great Britain (Mottier 2002; cf. EC (Osborn a.o.) 2000, 97).
} 
"difference" and social responsibility instead of on "pillars" and a non-committal tolerance in science and academia. In the mean time Dutch women scientists' motto should be clear: "Luctor et emergo!" (I struggle and come up). ${ }^{49}$

\section{References}

Arbeidsmarktmonitor academische sector 2001. Werkgelegenheid in de wetenschap in onderzoeken en ciffers. Een uitgave van SoFoKles in samenwerking met Research voor Beleid en de Vereniging van Samenwerkende Universiteiten VSNU.

AWT, KNAW, NWO, VSNU. 1999. Verslag van de conferentie 'Vrouwen in de wetenschap' d.d. 12 oktober 1999. S.a., s.l.

AWT-Advies: Adviesraad voor Wetenschaps- en Technologiebeleid. 2000. Halfslachtige wetenschap. Onderbenutting van vrouwelijk potentieel als existentieel probleem voor academia. Den Haag: SDU.

Balen, B. van. 2001. Vrouwen in de wetenschappelijke arena. Sociale sluiting in de universiteit. Amsterdam: Het Spinhuis.

Balen, B. van and A. Fischer, eds. 1998. De universiteit als modern mannenklooster. Amsterdam: Het Spinhuis.

Baranelli, M. e.a. 1990. Geachte promovenda, 110 jaar promoverende vrouwen aan de universiteit van Amsterdam. Amsterdam: SUA.

Beekes, A. 1991. De hordenloop. Ontwikkelingen in de achterstand van vrouwelijke op mannelijke academici aan Nederlandse universiteiten in de periode 1960-1985. Utrecht: Faculteit Sociale wetenschappen.

Berkel, K. van. 1985. In het voetspoor van Stevin. Geschiedenis van de natuurwetenschap in Nederland, 1580-1940. Meppel: Boom.

Berkel, K. van. 1990. "De amerikanisering van de Europese universiteit. Het begin van de discussie in Nederland (1900-1940)", in: Amerika in Europese ogen: facetten van de Europese beeldvorming van het moderne Amerika., edited by K. van Berkel. Den Haag: 135-160.

Berkel, K. van. 1998. Citaten uit het boek der natuur. Opstellen over Nederlandse wetenschapsgeschiedenis. Amsterdam: Bert Bakker.

Bertels, P. et al, eds. 1986. Het naadje van de blauwkous. Over een eeuw vrouwen in de wetenschap aan de RUU. Een uitgave bij de gelijknamige tentoonstelling van 9 maart - 20 april 1986. Buro Studium Generale/ Universiteitsmuseum. Utrecht.

Blok, P. J. 1907. "Vrouwelijke studenten." Onze Eeuw 7(3):447-426. (Ook in: Het Kind, tijdschrift voor ouders en opvoeders 9:69-70, 77-78, 86-87, 95-96, 103.

Blom, J. C. H. and J. Talsma, eds. 2000. De verzuiling voorbij. Gosdienst, stand en natie in de lange negentiende eeuw. Amsterdam: Het Spinhuis.

Bock, G. 2002. Women in European History. Oxford: Blackwell Publishers.

Boehm, L. 1958. "Von den Anfängen des akademischen Frauenstudiums in Deutschland. Zugleich ein Kapitel aus der Geschichte der Ludwig-Maximilians-Universität München." Historisches Jahrbuch 77:298-327.

Bonner, T. N. 1992. To the Ends of the Earth. Women's Search for Education in Medicine. Cambridge: Harvard University Press.

Bosch, M., I. Hoving, and G. Wekker. 1999. In het hart van de wetenschap. Naar Total E-quality en diversiteit in de universiteit. Background study Adviesraad voor Weten-schaps- en Technologiebeleid. Den Haag: SDU.

\footnotetext{
${ }^{49}$ This is the motto of the "water province" of Zeeland, which in its weapon shows a lion struggling to come up out of the water. Zeeland harbors the core of the "Delta works" which were started after the great flood of February 1953.
} 
Bosch, M. and M. Potting. 2001. "Vrouwen moeten door dat plafond heen." Evaluatie van het Aspasiaprogramma, eerste ronde: ervaringen, resultaten, effecten. In order of LOEKWO. Maastricht. (Evaluation study of Aspasia Program)

Bosch, M. 2000. "Wetenschap voor het vaderland: een wereld zonder vrouwen?" In Een vaderland voor vrouwen/A Fatherland for Women. The 'Nationale tentoonstelling van Vrouwenarbeid' in retrospect, edited by M. Grever and F. Dieteren, 167-182. Amsterdam: Stichting Beheer IISG.

Bosch, M. 1998. "Naar een deltaplan voor total E-quality in de universiteit?" Tijdschrift voor Genderstudies 1(4):46-54.

Bosch, M. 1997. "Kies exact! In historisch perspectief: veranderende visies op meisjesonderwijs en de exacte vakken, 1650-1880.” Gewina 20:184-210.

Bosch, M. 1994. "Het geslacht van de wetenschap. Vrouwen en hoger onderwijs, 1878-1948." Ph.D. diss., Erasmus Universiteit Rotterdam. Amsterdam: SUA.

Bosch, M. and A. Kloosterman. 1990. Politics and Friendship. Letters from the International Woman Suffrage Alliance, 1902-1942. Columbus: Ohio State University Press.

Bosch, M. and M. Hellevoort, eds. 2003. "De IJkpunten geijkt." Tijdschrift voor Sociale Geschiedenis March.

Bossenbroek, M. 1996. Holland op zijn breedst. Indië en Zuid-Afrika in de Nederlandse cultuur omstreeks 1900. Amsterdam: Bert Bakker.

Braat, J. 1991. "Leonardo daVinci en de kroonprinsen. Positieve actie voor vrouwen aan de Universiteit van Amsterdam." M.A thesis, UvA, Amsterdam.

Brittain, V. 1960. The Women at Oxford: A Fragment of History. London: George Harrap.

Brouns, M. 1988. Veertien jaar vrouwenstudies in Nederland; een overzicht. Zoetermeer: RION. English translation: 1990. The Development of Women's Studies. A Report from the Netherlands. Dordrecht: Foris.

Brouns, M. 2001. "Wetenschap tussen Olympus en Agora. De vele gezichten van gender in de wetenschappen." Tijdschrift voor Genderstudies 4(4):24-33.

Brouns, M. and H. Harbers. 1994. Kwaliteit in meervoud. Reflectie op kwaliteiten van vrouwenstudies in Nederland. Den Haag: VUGA.

Brouns, M. and M. Scholten. 1999. De kwaliteit van het oordeel. Een onderzoek naar beoordelings-procedures van KNAW en NWO. Uitgebracht door het NGV. Utrecht: NGV.

Burstyn, J. N. 1980. Victorian Education and the Ideal of Womanhood. London/Totowa, NJ: Croom Helm/ Barnes and Noble.

Clarke, E. H. 1873. Sex in Education. Boston: Osgood.

Committee on Women and Science, Engineering and Technology. 1994. The Rising Tide: A Report on Women and Science, Engineering and Technology. London: HMSO.

Cox, W. H. 1898. Over de aequivalentie van man en vrouw. Een biologische beschouwing. Print from Psyciatrische en Neurologische Bladen.

Davis, K. 1996. "What's a Nice Girl Like You Doing in a Place Like This? The Ambivalences of Professional Feminism.” In Borderlands: Feminism in the Academy, edited by L. Stamley, 184-196. London: Sage.

Davis, K. and M. Grünell. 1994. "The Dutch Case: An Interview with Margo Brouns." The Journal of Women's Studies 1:100-106.

De toekomst der academisch gegradueerden. 1936. Rapport van de commissie ter bestudeering van de toenemende bevolking der universiteiten en hoogescholen en de werkgelegenheid voor academisch gevormden. Groningen/Batavia: J. B. Wolters.

Dekker, R. 2000. De wetenschappelijke match. Persoon-cultuur fit en loopbanen van vrouwelijke en mannelijke wetenschappers. Amsterdam: Thela Thesis.

Drayer, E. 1999. 'Anneke Levelt Sengers'; 'Mieke Bal', interviews. In Bosch 1999, 39-43; 105-109.

Eijl, C. van. 1994. Het werkzame verschil. Vrouwen in de slag om de arbeid 1898-1940. Proefschrift UU. Hilversum: Verloren.

Essen, M. van 1990. Opvoeding met een dubbel doel. Twee eeuwen meisjesonderwijs in Nederland. Amsterdam: SUA. 
European Commission. Research Directorate-General. 2000. Science Policies in the European Union. Promoting Excellence Through Mainstreaming Gender Equality. A Report from the ETAN Expert Working Group on Women and Science. Luxembourg: Office for Official Publications of the European Communities.

Freie, M. J. 1948. “In opvoeding en onderwijs.” In Vrouwen van Nederland 1898-1948. De vrouw tijdens de regering van Koningin Wilhelmina, edited by M.G. Schenk, 89-107. Amsterdam: Scheltens \& Giltay.

Grever, M. 1994. Strijd tegen de stilte. Johanna Naber (1859-1941) en de vrouwenstem in geschiedenis. (Proefschrift KUN) Hilversum: Verloren.

Grever, M. 1997. "Controlling Memories: Gender and the Construction of Scientific History." Annali dell'Instituto storico italo-germanico in Trento. 12(1996):385-400.

Grever, M. and B. Waaldijk. 1998. Feministische openbaarheid. De Nationale Tentoonstelling van Vrouwenarbeid in 1898. Amsterdam: IISG.

Groen, M. G. 1987. Het wetenschappelijk onderwijs in Nederland van 1815 tot 1980. Een onderwijskundig overzicht. Deel I: Wetgeving, civiel effect, godgeleerdheid, rechtsgeleerdheid, indologie, geneeskunde. Z.p. [Eindhoven].

Grotenhuis, S. 1988. “Over geleerde vrouwen en geleerde feministen.” Tijdschrift voor Vrouwenstudies 24(6/4):395-412.

Hawkins, A. and G. Noordenbos. 1990. "Blokkades in het doorstromen van vrouwen naar hogere functies aan de universiteit." Universiteit en Hogeschool 36/5:269-279.

Hawkins, A. and D. Schultz. 1990. "Women: the Academic Proletariat in West Germany and The Netherlands." In Storming the Tower: Women in the Academic World, edited by S. Lie and V. O'Leary, 47-57. London/New York: Nicholson/GP Publishers.

Herwerden, C. A. B. van. 1948. Marianne van Herwerden, 16 Februari 1874-26 Januari 1934. Rotterdam: W. L. and L. Brusse.

Hicks, E. K. 1991. "Women at the Top in Science and Technology Fields. Profile of Women Academics at Dutch Universities." In Women in Science. Token Women or Gender Equality? Edited by V. StolteHeiskanen, 173-192. Providence/Oxford: Berg Publishers.

Hoving, I. 1999. "Lof der diversiteit.” In Bosch 1999, 111-139.

Idenburg, Ph. J. 1960. Schets van het Nederlandse schoolwezen. Groningen: : J. B. Wolters.

Idenburg, Ph. J. 1934. Studie, Crisis, Studiecrisis. Openbare les, gehouden bij de aanvaarding van het privaat-docentschap in de geschiedenis, theorie en statistiek van het schoolwezen aan de Universiteit van Amsterdam op 24 April 1934. Amsterdam.

Jacobs, A. H. [1924] 1996. Memories: My Life as an International Leader in Health, Suffrage and Peace. Edited by H. Feinberg and translated by A. Wright. New York: Feminist Press.

Jacobs, Aletta Henriette. 1879. Over Localisatie van Physiologische en Pathologische verschijnselen in de groote hersenen. Dissertation, University Groningen. Groningen: Oppenheim.

Jansen, W. 1996. “Women's Studies in the Netherlands.” Women's Studies Quarterly 1,2: 327-342.

Jansing, J. W. G. and L. Dasberg. 1978. "Het sociaal-culturele leven in Nederland, 1875-1895, 1895-1914: onderwijs." In Algemene Geschiedenis van Nederland (AGN). Deel 13 (Nieuwste Tijd): 129-144, 361-372.

Jensma, G. and H. de Vries. 1997. Veranderingen in het hoger onderwijs tussen 1815 en 1940. Hilversum: Verloren.

Jong, F. de. 1988. “'Die oude Aloë toch . . . Prof. Dr. Ir. Antonia E. Korvezee (1899-1978), de eerste vrouwelijke hoogleraar aan de Technische Hogeschool Delft," 227-234. In: Geleerde vrouwen. Jaarboek voor Vrouwengeschiedenis 9. Nijmegen: SUN.

Jong, O. J. de. 1982. “Benoemingsbeleid aan de Rijksuniversiteiten (1876-1931).” Rede bij de viering van de 346ste Dies Natalis der Rijksuniversiteit te Utrecht op 19 maart 1982 in de Janskerk. z.p. [Utrecht].

Keller, E. F. 1997. “Developmental Biology as a Feminist Cause?” Osiris 12:16-28.

Kelly, J. 1984. “Did Women Have a Renaissance?” In Women, History and Theory. The Essays of Joan Kelly, 19-50. Chicago: University of Chicago Press. 
Kerling, L. P. C. 1969. Phytopathologisch Laboratorium "Willie Commelin Scholten," 18 december 1894- 18 december 1969. Baarn: Mededeling.

Kerling, L. P. C., J. G. ten Houten, and G. de Bruin-Brink. 1986. "Johanna Westerdijk: Pioneer Leader in Plant Pathology." Annual Review of Phytopathology 24:33-41.

Kirejzcyk, M. 1988. "Marianne van Herwerden (1874-1934). De eerste vrouwelijke lector an de Rijksuniversiteit Utrecht." Geleerde vrouwen 146-151.

Kirejzcyk, M. 1993. "Vrouwen kozen exact; studie en beroepsuitoefening rond de eeuwwisseling." Gewina 16:234-247.

Kloosterman, G. J. 1992. "Hector Treub (1856-1920)" In Een brandpunt van geleerdheid in de hoofdstad, edited by J. H. C. Blom a.o., 119-140. Amsterdam: AUP.

Kolf, M. C. van der. 1950. Zeventig jaar Vrouwenstudie. Rotterdam: Brusse.

Kool-Smit, J. 1968. "Het onbehagen bij de vrouw." De Gids 130:267-281.

Kruyt, H. R. 1931. Hooge school en samenleving. Amsterdam.

Lasthuizen, K. 1995. Onderzoekers vrouwenstudies in Nederland: een overzicht. Utrecht: Nederlands Genootschap Vrouwenstudies.

Lie, S. S., L. Malik, and D. Harris, ed. 1994. The Gender Gap in Higher Education: World Yearbook of Education. London: Kogan Page.

Löhnis, M. P. 1963. Johanna Westerdijk Een markante persoonlijkheid. Met medewerking van enkele oudleerlingen en vrienden. Wageningen: Private publication.

Lorenz, C. 1993. Van het universitaire front geen nieuws. Baarn: Ambo.

Lucassen, H. and Th. Peeters. 1988. Hora Est. Gepromoveerde vrouwen aan de Katholieke Universiteit Nijmegen, 1923-1988. Centrum voor Vrouwenstudies van de Katholieke Universiteit Nijmegen. Nijmegen.' Unpublished paper.

Lykke, N. 2001. "Women in Science: Sweden versus Denmark. A Case Story about Neighbouring Countries with Different Gender Profiles." Unpublished paper.

Maas, A. 2001. "Tachtigers in de wetenschap. Een nieuwe kijk op het ontstaan van de Tweede Gouden eeuw in de Nederlandse natuurwetenschap." Tijdschrift voor Geschiedenis 114/3:354-376.

Massachusetts Institute of Technology. 1999. A study on the Status of Women Faculty in Science at MIT. Massachusetts: MIT. http://web.mit.edu/fnl/women/women.htlm.

Maudsley, H. 1874. "Sex in Mind and Education." Fortnightly Review 15:466-483.

Meijer, I. C. 1996. Het persoonlijke wordt politiek. Feministische bewustwording in Nederland, 1965-1980. Amstertdam: Het Spinhuis.

Mercier, H. 1911. "Wegwijzers." In Verbonden schakels, by H. Mercier, 13-36. Amsterdam: Maatschappij voor goede en goedkope lectuur.

Ministerie van Onderwijs, Cultuur en Wetenschappen. 1979. Beleidsnota Universitair Onderzoek. 'sGravenhage: sdu.

Ministerie van Onderwijs, Cultuur en Wetenschappen. 1981. Kernnota inzake beleidsvoornemens betreffende het universitair wetenschappelijk personeel. 's-Gravenhage: sdu.

Ministerie van Onderwijs, Cultuur en Wetenschappen. 1982. Beleidsnota taakverdeling en concentratie in het weten-schappelijk onderwijs; standpunt van de minister. 's-Gravenhage: sdu.

Ministerie van Onderwijs, Cultuur en Wetenschappen. 1985. Hoger Onderwijs: Autonomie en Kwaliteit (hoak). 's-Gravenhage: sdu.

Ministerie van Onderwijs, Cultuur en Wetenschappen. 1986. Het proces van taakverdeling en concentratie in het wetenschappelijk onderwijs. 's-Gravenhage: sdu.

Mottier, I. 2002. "Women and Science: Review of the situation in the Netherlands." Helsinki Report. (http://www.cordis.lu/improving/women/reports.htm.)

Noordenbos, G. 2000 s.a. Vrouwen in de Academies van Wetenschappen. Van uitsluiting tot uitzondering. Zutphen: Walburg Pers.

Noordenbos, G. 1993-94. “Dat was niet te voorzien': consequenties van universitaire reorganisatie voor de man/vrouw-verdeling." Universiteit en Hogeschool (Special issue 'In dienst van Alma Mater' of 'Hoe aantrekkelijk is de universiteit als werkgever'). 40(3):107-117. 
Noordenbos, G. 1994-1995. “Gender gap in Academe': de positie van vrouwen aan de universiteit in internationaal perspectief." $U$ and $H$ 41(3):105-120.

Noordenbos, G. 1999. 'Genderasymmetrie in de aanvraag van onderzoekssubsidies.' Tijdschrift voor Genderstudies 2(4):36-45.

Oreskes, N. 1996. "Objectivity or Heroism? On the Invisibility of Women in Science." Osiris 10:87-113.

Phillips, P. 1990. The Scientific Lady: A Social History of Women's Scientific Interests, 1520-1918. London: Weidenfeld and Nicholson.

Plantenga, J. 1993. Een afwijkend patroon. Honderd jaar vrouwenarbeid in Nederland en (West) Duitsland. Amsterdam: SUA.

Portegijs, W. 1998. "Eerdaags evenredig? Belemmeringen en beleid ten aanzien van de doorstroom van vrouwen naar hogere wetenschappelijke functies." Beleidsgerichte studies Hoger Onderwijs en Wetenschapsbeleid. Den Haag: SDU.

Posthumus van der Goot, W. H. and A. de Waal, eds. [1948] 1977. Van Moeder op Dochter. De maatschappelijke positie van de vrouw in Nederland vanaf de franse tijd. Nijmegen: SUN.

Pouwelse, W. J. 1993. Haar verstand dienstbaar aan het hart. Middelbaar onderwijs voor meisjes, debatten, acties en beleid. Tilburg: Het Spinhuis.

Rapport van de Staatscommissie tot Reorganisatie van het Hoger Onderwijs. 1949. Voorzitter: H.J. Reinink. Ingesteld bij KB van 11 april 1946. 's-Gravenhage.

Rees, T. 2002. National Policies on Women and Science in Europe. The Helsinki Group on Women and Science. EC, Directorate-General for Research, Women and Science.Luxembourg, Office for Official Publications of the European Communities.

Ribberink, A. 1998. Leidsvrouwen en zaakwaarneemsters. Een geschiedenis van de Aktiegroep Man Vrouw Maatschappij (MVM), 1968-1973. Hilversum:Verloren.

Rooy, P. de. 2001. “Voorbij de verzuiling?” BMGN. 116(1):45-57.

Rooy, P. de. 2002. Republiek van rivaliteiten. Nederland sind 1813. Amsterdam: Mets en Schilt.

Rose, H. 1994. Love, Power and Knowledge: Towards a Feminist Transformation of the Sciences. Cambridge: Polity Press.

Rossi, A. S. 1965. "Women in Science: Why So Few?” Science 148:1196-1202.

Rossiter, M. W. 1984. Women Scientists in America: Struggles and Strategies to 1940. Baltimore: Johns Hopkins University Press.

Rossiter, M. W. 1997. “Which Science? Which Women?” Osiris 12:169-185.

Rupp, J. C. C. 1997. Van oude en nieuwe universiteiten. De verdringing van Duitse door Amerikaanse invloeden op de wetenschapsbeoefening en het hoger onderwijs in nederland, 1945-1995. Den Haag: SDU.

Schiebinger, L. 1989. The Mind Has No Sex? Women in the Origins of Modern Science. Cambridge: Harvard University Press.

Schiebinger, L. 1997. "Creating Sustainable Science.” Osiris 12:201-216.

Schoon, L. 1989. Het ideaal van de nieuwe vrouw. Catharine van Tussenbroek (1852-1925). Doctoraalscriptie Politieke Theorie en Nieuwste Geschiedenis, UvA. Amsterdam.

Schoor, W. van der. 1994. "Biologie en landbouw. F. A. F. C. Went en de Indische proefstations." Gewina $17: 145-161$.

Scott, J. W. 1988. Gender and the Politics of History. New York: Columbia University Press.

Shteir, A. B. 1996. Cultivating Women, Cultivating Science: Flora's Daughters and Botany in England 1760 to 1860. Baltimore: Johns Hopkins University Press.

Soden, K. von. (1979) "Zur Geschichte des Frauenstudiums." In 70 Jahre Frauenstudium. Frauen in der Wissenschaft, edited by K. von Soden and G. Zipfel, 9-42. Köln: Pahle-Rugenstein.

Solomon, B. M. 1985. In the Company of Educated Women: A History of Women and Higher Education in America. New Haven: Yale University Press.

Stamhuis, I. H. 1995. "A Female Contribution to Early Genetics: Tine Tammes and Mendel's Laws for Continuous Characters." Journal of the History of Biology 28:495-531. 
Steen, M. van der. 1998. "Op leeftijd. Wetenschapsbeleid en seksediscriminatie." Tijdschrift voor Genderstudies 1:50-53.

Steinmetz, S. R. 1934. “De overvulling onzer universiteiten.” Paedagogische Studiën 15:280-291.

Stevens, I., I. van Lamoen. 2001. Manual on Gender Mainstreaming at Universities. Leuven-Apeldoorn: Garant.

Sturkenboom, D. 2001. "Une société savante exclusivement féminine. Présage des temps modernes ou vestige de Áncien Régime?” Annales historiques de la Révolution française 4:117-127.

Treub, H. and C. Winkler. 1898. De vrouw en de studie. Voordrachten en debatten gehouden in de vergadering van 3 Maart en 10 November 1898 van de Vereeniging ter Behartiging van de Belangen derVrouw' te Rotterdam. Haarlem.

Tussenbroek, C. van. [1898] Over het tekort aan levensenergie bij onze jonge vrouwen en meisjes. Rede uitgesproken door Dr. Catharine van Tussenbroek op de Nationale Tentoonstelling van Vrouwenarbeid. S.l. s.a.

Tussenbroek, C. van. 1898. Over de aequivalentie van man en vrouw. Weerlegging van de biologische beschouwing van Dr.W.H. Cox uit Deventer. Print from Belang en Recht.

Verhaar, O. 1991. Prima inter pares. Over de voorkeursbehandeling van vrouwen. Analyse van de argumentatiestrategieën van voor-en tegenstanders in de openbare discussie over het voorkeursbeleid. 'sGravenhage: Vuga.

Vianen, A. E. M. van. 1997. Het selectie interview. Over de rol van stereotypen. Academisch Proefschrift. Leiden: RUL.

Vucht Tijssen, B. E. van. 2000. Talent voor de Toekomst. Toekomst voor Talent. Plan van aanpak voor het wetenschapsbeleid. Utrecht.

Wachelder, J. C. M. 1992. Universiteit tussen vorming en opleiding. De modernisering van de Nederlandse universiteiten in de negentiende eeuw. Hilversum: Verloren.

Wekker, G. 1999. "De belofte van gender- en vrouwenstudies.” In Bosch 1999, 149-168.

Wennerås, C. and A. Wold. 1997. "Nepotism and sexism in peer-review." Nature 387:341-343.

Weyrather, I. 1981. “'Die Frau im Lebensraum des Mannes.' Studentinnen in der Weimarer Republik." Beiträge 5 zur feministischen Theorie und Praxis. Dokumentation des 3. Historikerinnentreffens in Bielefeld, April 1981, 25-39. München: Verlag Frauenoffensive.

Wilde, I. de. 1978. Aletta Jacobs in Groningen. Groningen: Studium Generale/ Universiteitsmuseum/ RUG.

Wilde, I. de. 1985. “'Er is een heilig móeten, waartegen geen bezwaar is bestand.' De betekenis van Hélène Mercier (1839-1910) voor de vrouwenbeweging." De eerste feministische golf. Jaarboek voor vrouwengeschiedenis 6, 59-77. Nijmegen: SUN.

Wilde, I. de. 1989. "Jantina Tammes (1871-1947), Nederlands eerste hoogleraar in de erfelijkheidsleer." Om niet aan onwetendheid en barbarij t4e bezwijken. Groningse geleerden 1614-1989. Edited by G. A. van Gemert, J. Schuller tot Peursum-Meijer, A. J. Vanderjagt, 187-206. Hilversum: Verloren.

Wilde, I. de. 1998. Nieuwe deelgenoten in de wetenschap. Vrouwelijke studenten en docenten aan de rijksuniversiteit Groningen, 1871-1919. Proefschrift UVA. Assen: Van Gorcum.

Willink, B. 1980. "Een inleiding tot de Tweede Gouden Eeuw. De wetten van 1863 en 1876 en de wedergeboorte van de Nederlandse natuurwetenschap." Hollands Maandblad 22:391-392 (juni/juli 1980):3-9.

Willink, B. 1998. De tweede gouden eeuw. Nederland en de Nobelprijzen voor natuurwetenschappen 1870-1940. Amsterdam: Bert Bakker.

Winkler, C. [1901] 1918. "Het hooger onderwijs in de geneeskunde." In Opera Omnia, III, Cornelis Winkler, 515-539. Haarlem: Tjeenk Willink. 